\title{
Metabolic Syndrome: Is It Time to Add the Central Nervous System?
}

\author{
Milagros Rojas ${ }^{1}$, Mervin Chávez-Castillo ${ }^{2}$, Daniela Pirela ${ }^{1}$, Heliana Parra ${ }^{1}{ }^{1}$, Manuel Nava ${ }^{1}$, \\ Maricarmen Chacín ${ }^{3}$, Lissé Angarita ${ }^{4}\left(\mathbb{D}\right.$, Roberto Añez ${ }^{5}$, Juan Salazar ${ }^{1}{ }^{\circledR}$, Rina Ortiz ${ }^{6}$, Samuel Durán Agüero ${ }^{7}$, \\ Marbel Gravini-Donado ${ }^{8}$, Valmore Bermúdez ${ }^{9}$ (i) and Edgar Díaz-Camargo ${ }^{9, *(1)}$
}

1 Endocrine and Metabolic Diseases Research Center, School of Medicine, University of Zulia, Maracaibo 4004, Venezuela; migarocafi@gmail.com (M.R.); pirelacdaniela@gmail.com (D.P.); helianapp20@hotmail.com (H.P.); manuelnava_14@hotmail.com (M.N.); juanjsv18@hotmail.com (J.S.)

2 Psychiatric Hospital of Maracaibo, Maracaibo 4004, Venezuela; mervinch@hotmail.com

3 Facultad de Ciencias de la Salud, Universidad Simón Bolívar, Barranquilla 08002, Colombia; m.chacin@unisimonbolivar.edu.co

4 Escuela de Nutrición y Dietética, Facultad de Medicina, Universidad Andrés Bello, Sede Concepción 4260000, Chile; lisse.angarita@unab.cl

5 Departamento de Endocrinología y Nutrición, Hospital General Universitario Gregorio Marañón, 28007 Madrid, Spain; robertojose.anez@salud.madrid.org

6 Posgrado, Carrera de Medicina, Universidad Católica de Cuenca, Cantón de Cuenca 010101, Ecuador; rortiz@ucacue.edu.ec

7 Facultad de Ciencias Para el Cuidado de la Salud, Universidad San Sebastián, Los Leones 8420524, Chile; samuel.duran@uss.cl

8 Facultad de Ciencias Jurídicas y Sociales, Universidad Simón Bolívar, Barranquilla 080002, Colombia; mgravini1@unisimonbolivar.edu.co

check for updates

Citation: Rojas, M.; Chávez-Castillo, M.; Pirela, D.; Parra, H.; Nava, M.; Chacín, M.; Angarita, L.; Añez, R.; Salazar, J.; Ortiz, R.; et al. Metabolic Syndrome: Is It Time to Add the Central Nervous System? Nutrients 2021, 13, 2254. https://doi.org/ $10.3390 /$ nu13072254

Academic Editors: Omorogieva Ojo and Amanda Adegboye

Received: 21 May 2021

Accepted: 9 June 2021

Published: 30 June 2021

Publisher's Note: MDPI stays neutral with regard to jurisdictional claims in published maps and institutional affiliations.

Copyright: (c) 2021 by the authors. Licensee MDPI, Basel, Switzerland. This article is an open access article distributed under the terms and conditions of the Creative Commons Attribution (CC BY) license (https:/ / creativecommons.org/licenses/by/ $4.0 /)$.
9 Facultad de Ciencias Jurídicas y Sociales, Universidad Simón Bolívar, Cúcuta 540006, Colombia; v.bermudez@unisimonbolivar.edu.co

* Correspondence: e.diaz@unisimonbolivar.edu.co

\begin{abstract}
Metabolic syndrome (MS) is a set of cardio-metabolic risk factors that includes central obesity, hyperglycemia, hypertension, and dyslipidemias. The syndrome affects $25 \%$ of adults worldwide. The definition of MS has evolved over the last 80 years, with various classification systems and criteria, whose limitations and benefits are currently the subject of some controversy. Likewise, hypotheses regarding the etiology of MS add more confusion from clinical and epidemiological points of view. The leading suggestion for the pathophysiology of MS is insulin resistance (IR). IR can affect multiple tissues and organs, from the classic "triumvirate" (myocyte, adipocyte, and hepatocyte) to possible effects on organs considered more recently, such as the central nervous system (CNS). Mild cognitive impairment (MCI) and Alzheimer's disease (AD) may be clinical expressions of CNS involvement. However, the association between MCI and MS is not understood. The bidirectional relationship that seems to exist between these factors raises the questions of which phenomenon occurs first and whether MCI can be a precursor of MS. This review explores shared pathophysiological mechanisms between MCI and MS and establishes a hypothesis of a possible $\mathrm{MCI}$ role in the development of IR and the appearance of MS.
\end{abstract}

Keywords: metabolic syndrome; insulin resistance; diabetes mellitus type 2; mild cognitive impairment; Alzheimer's disease

\section{Introduction}

Metabolic syndrome (MS) is a serious public health problem. It affects about $25 \%$ of the general population and, more alarmingly, around $40 \%$ of adults over 40 years old worldwide [1,2]. The definition of this syndrome has recently evolved to include a group of at least three of five cardio-metabolic abnormalities. These conditions include high blood pressure, central obesity, insulin resistance (IR), elevated blood triglycerides, and atherogenic dyslipidemia [3], which together lead to an increased risk of cardio-metabolic pathologies [4-6], as well as other diseases, such as arthritis [7] and some types of cancer [8]. 
Likewise, the presence of MS-related disorders also plays a role in the pathophysiology of neurological disorders [9], reflecting the association between deficiencies in secretion and action of insulin and mild cognitive impairment (MCI) [10]. MCI is defined as cognitive dysfunction that exceeds what is typically expected for age and educational level but does not meet the criteria for a major neurocognitive disorder. General functionality is preserved in $\mathrm{MCI}$ [11] and it can be best described as an intermediate state between cognitive impairment characteristic of aging and major neurocognitive conditions, such as Alzheimer's disease (AD) [12,13].

Pathophysiological mechanisms of MCI have not been fully clarified. Thus, different hypotheses are proposed to explain the MCI/MS association [14]. A cyclical relationship seems to exist between IR and cognitive impairment, and the question of which phenomenon occurs first arises [15]. Additionally, if cognitive impairment precedes IR, it becomes a risk factor for developing MS. Therefore, this review briefly describes the history of MS and discusses clinical and preclinical findings that support the role of MS and IR as elements of pathophysiological mechanisms of cognitive impairment.

While most reviews on the topic focus on the MS-to-MCI relationship, this review goes beyond this by looking at the inverse relationship, examining available evidence regarding a new hypothesis that suggests that cognitive impairment could have a role in the development of IR and the appearance of MS. Among the mechanisms to be highlighted in this regard, the hyperphosphorylation of tau proteins and the formation of amyloid $\beta(A \beta)$ plaques are proposed as alterations that go beyond the pathophysiology of Alzheimer's disease (AD), and their role in the pathophysiology of insulin alterations is examined.

\section{Metabolic Syndrome: Historical Aspects}

The first studies of MS started almost 100 years ago when Eskil Kylin, in 1921, and Gregorio Marañón, in 1922, independently published in the same journal (Zentralblatt für Innere Medizin) papers with the same title, "diabetes mellitus and hypertension" [16,17]. Yet, not until 1981 did Hanefeld and Leonhardt use the term "metabolic syndrome" for the first time [18].

In 1988, Gerald Reaven hypothesized that IR was a common etiological factor for a group of disorders he termed "Syndrome X" $[19,20]$. He used this name to emphasize its unknown origin. At this time, the fundamental pathophysiological role of IR was known. This mechanism had been studied by researchers, such as Randle [21]. In subsequent years, DeFronzo, Ferrannini, and others used the term "Insulin Resistance Syndrome", proposing that available evidence suggested its presence was the cause of MS [22].

The cause of MS and its components have been debated worldwide since the end of the 20th century. Many organizations, such as the World Health Organization (WHO) [23], the European Group for the Study of Insulin Resistance (EGIR) [24], the Adult Treatment Panel III (ATP-III) [25], the American Association of Clinical Endocrinologists (ACE/AACE) [26], and the International Diabetes Federation (IDF) [27], have proposed evolving diagnostic criteria. Some criteria have been progressively discarded and replaced with criteria that can be easily applied in daily clinical practice.

Finally, the IDF, the National Heart, Lung, and Blood Institute, the American Heart Association, the World Heart Federation, the International Atherosclerosis Society, and the International Association for the Study of Obesity made a joint statement in 2009 that concluded that a diagnosis of MS requires the presence of three or more of the following criteria: high abdominal circumference as defined for each geographical region, triacylglycerides (TAG) greater than or equal to $150 \mathrm{mg} / \mathrm{dL}$, HDL levels less than $50 \mathrm{mg} \%$ in women or less than $40 \mathrm{mg} \%$ in men, systolic blood pressure (SBP) greater than or equal to $130 \mathrm{mmHg}$ or diastolic blood pressure (DBP) greater than or equal to $85 \mathrm{mmHg}$, and glycemic levels greater than $100 \mathrm{mg} / \mathrm{dL}$ [3]. We now consider that the evolution of diagnostic criteria has reached a maturity level that makes it difficult to incorporate new criteria that are both easily recognized and provide useful clinical information [28]. IR continues to be the most 
widely accepted hypothesis to describe MS pathophysiology that involves various organs and associations with numerous diseases [29].

\section{Mild Cognitive Impairment and Metabolic Syndrome: Molecular Basis}

Epidemiological, clinical, and experimental evidence provides a solid basis for the hypothesis that IR is the pathophysiological origin for dyslipidemias, high blood pressure, and disorders in glucose homeostasis [30]. As studies of MS continued, a relationship emerged between obesity, the syndrome's most prevalent individual criterion, and neurological alterations [31]. This association necessitates additional consideration of the pathophysiological mechanisms involved and how they are interconnected.

\subsection{From Metabolic Syndrome to Cognitive Impairment}

Epidemiological [32], neuroimaging [33], and animal modeling studies are available to characterize MS pathophysiology, accompanying diseases, and individual components in the development of neurodegenerative diseases and associated cognitive impairment [34]. The connection between diabetes mellitus (DM) and $\mathrm{AD}$ and the connection between obesity and cognitive impairment are two areas that have been investigated in depth, including reports of statistically significant relationships $[10,35,36]$.

The hippocampus plays an important role in learning and memory. The effect of IR on hippocampal function has been widely studied [37]. Lindqvist et al. administered highand low-fat diets to different groups of rats, using bromodeoxyuridine (BrdU) to observe synaptogenesis after 4 weeks. Male rats fed the high-fat diet showed a significant decrease in neurogenesis in the hippocampus. The animals did not develop obesity [38]. This result could reflect the role of lipid alteration, a component of MS, in cognitive decline.

Karimi et al. studied long-term neuronal potentiation (LTP) in the dentate gyrus (DG) of the hippocampus in mice receiving different combinations of a high-fat diet and antioxidants. Mice fed a high-fat diet showed lower LTP levels compared with control animals. In contrast, mice that received antioxidants displayed elevated LTP [39]. These effects might be mediated by an increase in free radical production caused by the high-fat diet, leading to oxidative stress (OS). This hypothesis is supported by rescue of LTP levels through the administration of antioxidants [39].

\subsubsection{Role of IR in the Formation of Amyloid-Beta Plaques}

Production of reactive oxygen species (ROS) results in increased levels of amyloid precursor peptide- $\beta$ (A $\beta \mathrm{PP})$ and increased expression and accumulation of amyloid- $\beta 42$ (A $\beta$ ) [40]. This accumulation leads to the formation of amyloid-beta plaques, identified as a key element of AD [41]. One pathway for increased ROS production is increased insulin levels that lead to changes in normal NADPH oxidase (NOX4) pathway function. Elevated insulin levels induce phosphoinositol-3 kinase (PI3K) to phosphorylate Rac instead of phosphatidylinositol bisphosphate (PIP2). This alteration increases NOX4 activity and ROS levels. This aberrant metabolism is perpetuated because elevated ROS leads to activation of casein kinase 2 (CK2) and consequent activation of the retromer. This action signals the degradation of glucose receptor, GLUT4, leading to a continued increase in glucose levels in the blood and, therefore, increased production of insulin [42] (Figure 1).

The metabolic syndrome (MS) and its components cause brain alterations such as neuroinflammation, hyperphosphorylation of Tau, formation of beta amyloid plaques, and vascular changes (not represented in the figure). This is achieved through changes in the signaling of hormones such as adiponectin, leptin, and insulin. These changes are clinically expressed as mild cognitive impairment (MCI), Alzheimer's disease (AD), and major vascular neurocognitive disorder. 


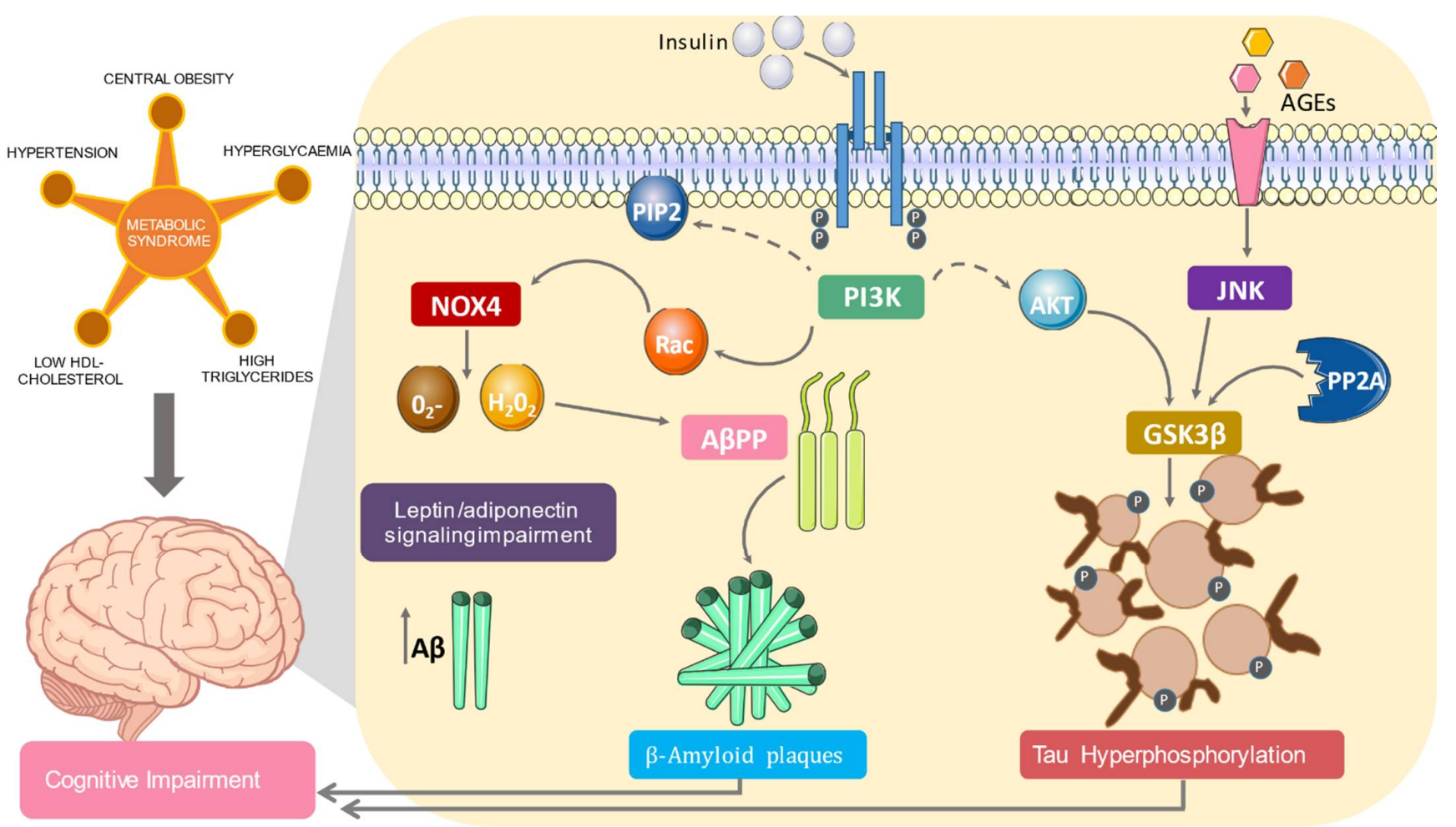

Figure 1. Impact of metabolic syndrome on cognitive impairment. PIP2: phosphatidylinositol bisphosphate; AKT: protein kinase B; PI3K: phosphoinositide kinase-3; JNK: c-Jun N-terminal kinase; AGEs: advanced glycation end products; PP2A: protein phosphatase $2 \mathrm{~A}$; GSK3 $\beta$ : glycogen synthase kinase 3 beta; NOX4: NADPH oxidase 4; 02-: superoxide; $\mathrm{H}_{2} \mathrm{O}_{2}$ : hydrogen peroxide; $\mathrm{A} \beta$ : amyloid beta. Solid lines mean activation; dashed lines mean inactivation.

This positive feedback produces an environment of neuronal inflammation, reported as a risk factor for $\mathrm{AD}$. An associated hypothesis is that, along with neurofibrillary tangles and amyloid-beta plaques, inflammation has a critical role in the pathophysiology of the disease [43]. Insulin seems to play a significant role in the development of plaques, and hyperinsulinemia observed in IR leads to their formation. In vitro studies show that high levels of insulin affect the degradation and elimination of $A \beta$. Both insulin and $A \beta$ are degraded by insulin-degrading enzyme (IDE). During hyperinsulinemia, IDE degrades insulin preferably to $A \beta$, promoting its oligomerization into insoluble aggregates [44]. In vivo experiments in rats corroborate these findings, showing that elimination of $A \beta$ is reduced in the presence of high levels of insulin [45].

Insulin receptors provide an alternative explanation for IR effects on the hippocampus and other brain structures [46]. These receptors are abundant in metabolic active brain areas and exert their effects at the neuronal level via PI3K and mitogen-activated protein kinases (MAPK) pathways [47]. These pathways, when activated by insulin, promote angiogenesis in the brain. In the presence of IR, these pathways are not activated. This disruption might underlie the concomitant synaptic anomalies, memory disorders, decreases in neurogenesis at the hippocampus level, alterations in cognition, and decreases in levels of brain-derived neurotrophic factor (BDNF) [46].

\subsubsection{Metabolic Syndrome, Insulin Resistance, and Tau Proteins}

Conversely, tau protein (TP) helps stabilize microtubules and its alteration results in the formation of neurofibrillary tangles [48]. Further, IR induces hyperphosphorylation of TP and induces cognitive impairment in human and animal models [49,50]. Thus, IR is associated with poorer performance on cognitive tests and higher levels of phosphorylated PT in cerebrospinal fluid (CSF) in cognitively normal individuals and carriers of the APOE allele $\varepsilon 4[10,51]$. 
One mechanism underlying this phenomenon involves glycogen synthase kinase$3 \beta$ (GSK3 $\beta$ ), a tau kinase regulated by insulin via the protein kinase B (AKT) pathway. Decreased brain insulin signaling caused by IR induces chronic exposure of neurons to high levels of insulin or an eventual decrease in insulin levels, resulting in PI3K dysfunction and reduced AKT-dependent phosphorylation. Downstream, GSK3 $\beta$ is activated, and ultimately TP is hyperphosphorylated [52,53]. The production of advanced glycation end products (AGEs) from OS damage via GSK3 $\beta$ receptors (RAGE) also increases the activity of GSK3 $\beta$ by an alternate pathway involving c-Jun N-terminal kinase (JNK) [54].

A recent study showed protein kinase A (PKA) is a potent tau kinase and its activation increases TP hyperphosphorylation in an insulin-deficient animal model [55]. Moreover, insulin deficiency influences hyperphosphorylated TP level by decreasing the activity of protein phosphatase 2 (PP2A) [56]. PP2A is the primary tau phosphatase involved in $\mathrm{AD}$ and its deregulation is associated with TP hyperphosphorylation [57]. Similarly, hypothermia, common in chronic DM, also leads to inhibition of PP2A activity [58].

Another pathological mechanism in AD is truncation of TP by proteolytic enzymes, such as caspases, peptidases, and thrombins that promote tau aggregation and formation of the central component of neurofibrillary tangles (NFT) [59]. DM stimulates apoptosis through the activation of caspases in affected tissues. Through hyperglycemia, DM might increase tau aggregation by activating caspases, thus contributing to AD risk [60]. Kim et al. demonstrated such increased tau aggregation in the brain of $\mathrm{db} / \mathrm{db}$ rats using in vivo and in vitro type 2 diabetes mellitus (T2DM) animal models [61].

\subsubsection{Metabolic Syndrome, Leptin, Adiponectin, and Cognitive Disorders}

Alterations in hormones involved in MS, such as leptin and adiponectin, are also linked to cognitive impairment [62]. Both hormones affect the metabolism of fatty acids and glucose as well as energy metabolism and food intake [63,64]. Their function in neuroplasticity, learning, and cognition $[65,66]$ is now known via reports of leptin and adiponectin receptor expression in brain regions such as the hippocampus and neocortex [67].

Recent studies in animal models show that leptin deficiency or resistance is associated with cognitive disorders, such as reductions in LTP, long-term neuronal depression (LTD), and alterations in spatial memory [68]. Further, leptin modulates the production and elimination of $A \beta$ in $A D$ by inhibiting the formation of $A \beta P P$ and increasing APOE $\varepsilon 4$-induced amyloid filament elimination. This activity may be mediated through the activation of AMP-activated protein kinase (AMPK) $[69,70]$. Leptin resistance in AD is associated with diminished activity in these pathways and increased cognitive impairment [71].

Additionally, adult rats deprived of adiponectin display several common characteristics of $\mathrm{AD}$, including deposition of $\mathrm{A} \beta$, TP phosphorylation, and neuroinflammation [72]. This observation is corroborated by Kim et al., who demonstrated that adiponectin receptor suppression also produced an AD-like phenotype [73] Thus, hormone deficiencies might be involved in $\mathrm{AD}$ pathogenesis. However, studies in humans are controversial since available information for the association of adiponectin and leptin levels in the blood and CSF with cognitive impairment is inconclusive [62].

\subsubsection{Metabolic Syndrome, Microvasculature, and Cognitive Impairment}

Micro- and macrovascular changes observed in MS, such as hypertension and DM, are also associated with brain alterations, such as vascular neurocognitive disorder. However, several recent studies note the contribution of vascular risk factors in AD. Mechanisms for this accelerating cognitive decline are not fully elucidated [74].

Hypertension leads to alterations observed in magnetic resonance imaging (MRI), such as white matter lesions (WML), lacunar infarcts, microhemorrhages, and microinfarcts. All these abnormalities are part of a spectrum called small vessel cerebral disease (SVD), which is common in AD [75]. SVD is characterized by loss of smooth muscle cells in the mid-tunic, deposition of fibro-hyaline material, reduced light, and thickening of vascular walls [76]. Moss et al. studied Rhesus monkeys using an aortic coarctation model. 
Multiple microinfarcts and lesions in gray and white matter in hypertensive monkeys were associated with cognitive impairment [77]. Other mechanisms might involve large arteries via endothelial dysfunction that progresses to the formation of atherosclerotic plaques in the carotid or intracranial arteries. Such damage can cause ischemic events in brain regions related to cognition [78].

\subsection{Exploring the Inverse Relationship -From Cognitive Impairment to Metabolic Syndrome}

The consequences of MS on the development of cognitive impairment have been studied in depth [79], but the inverse relationship in which pathophysiological mechanisms of $\mathrm{AD}$, such as hyperphosphorylation of TP and the formation of amyloid complexes- $\beta$, lead to the appearance of MS is largely unstudied.

\subsubsection{Tau Proteins and Deficits in Insulin Signaling}

Interestingly, TPs, in addition to microtubule stabilization, also interact with insulin signaling pathway components in the brain. The N-terminal portion of TP can bind to homology 3 (SH3) domains of the Src family of tyrosine kinases, including domains of the $\mathrm{p} 85$ alpha subunit of PI3K, a key protein in the insulin signaling pathway. Under pathological conditions, hyperphosphorylation of TPs can lead to loss of functionality, triggering alterations in insulin signaling that eventually generate altered fasting glycemia and DM. The ability of TPs to interact with SH3 domains is inversely correlated with the degree of phosphorylation, suggesting that scaffolding properties of TPs are regulated by their phosphorylation status [80].

Further, co-immunoprecipitation studies of mouse brain tissue and N1E115 cells indicate that TPs bind to phosphatase and tensin homologous protein (PTEN), a negative insulin signal translocation regulator that catalyzes dephosphorylation of phosphatidylinositol triphosphate (PIP3) to PIP2. Thus, TP, by interacting with and inhibiting PTEN, promotes insulin signaling [81]. These studies raise the possibility that insulin helps maintain adequate brain activity due to TP and, conversely, pathological forms of TP could be harmful due to a loss of protein function. This suggestion is supported by a study that showed that TP removal was accompanied by loss of inhibitory effects of insulin on PTEN in the hippocampus, resulting in brain IR.

Concurrently, the absence of TP reduced the anorexigenic effect of insulin in the hypothalamus after intracerebroventricular injection of TP [81]. Previously, such injection induced increased food intake, weight gain, adiposity, hyperinsulinemia, and glucose intolerance in rodents with insulin receptor deletion in the hypothalamus $[82,83]$. These effects produce alterations in energy metabolism that may increase the risk of suffering from obesity, DM, and MS.

TP is also highly expressed in pancreatic islet $\beta$-cells. However, its function in peripheral tissues is not fully understood [84,85]. Wijesekara et al. investigated TP actions on $\beta$-cell function and glucose homeostasis using a tau KO rat model. Rats showed weight gain, defects in glucose signaling, and IR, leading to DM and ultimately MS. Thus, TP might be crucial for normal energy metabolism in peripheral tissues [86].

\subsubsection{Amyloid $\beta$ and Insulinemic Alterations}

In vitro and in vivo studies suggest that $A \beta$ may also contribute to IR through various mechanisms. A $\beta$ competitively inhibits the binding of insulin to its receptor [87] and activates the JAK2/STAT3/SOCS-1 signaling pathway to produce IR in the liver [88]. Further, the oligomer $A \beta(A \beta O)$, a highly toxic species of $A \beta$, causes deregulation of $\mathrm{N}$-methyl-D-aspartate (NMDA) receptors and leads to the production of excessive ROS. This effect is probably due to mitochondrial dysfunction [89].

This deregulation might lead to alterations in insulin signaling, since increased ROS activates several serine kinases, such as an inhibitor of the nuclear factor kappa-B kinase beta subunit (IKK- $\beta$ ), protein kinase C (PKC), and JNK. These kinases increase phosphorylation in Ser IRS-1 residues. ROS can cause OS and damage at mitochondrial and cellular 
levels. This stress generates mitophagy and, at high levels of stress, apoptosis. The elimination of mitochondria by mitophagy results in a decrease in oxidation and consequent accumulation of lipids, leading to IR and T2DM [90].

Conversely, A $\beta O$ causes a rapid and substantial loss of insulin receptors in dendrites and inhibition of insulin receptor autophosphorylation associated with NMDA activity [91]. Additionally, an increase in levels of IR markers p(Ser)-IRS-1 and p-JNK were observed in neurons after intracerebroventricular injection of $A \beta O$ in vivo in monkeys [92].

\subsubsection{Amyloid $\beta$, Tau Protein, and Leptin}

$\mathrm{A} \beta$ and TP have also been linked to alterations in leptin signaling. Bonda et al. showed that TP hyperphosphorylation leads to the formation of NFT and dysfunction in intracellular trafficking networks in the hippocampus. Thus, the leptin receptor in its long form $(\mathrm{Ob}-\mathrm{Rb})$ becomes unable to reach cell membranes, hindering its access to circulating free leptin and interrupting signaling. This activity might lead to increased food intake and weight gain with subsequent development of obesity and long-term MS [93]; leptin in the hippocampus is associated with regulating food intake and processing food-related memories [94].

Elevated levels of A $\beta 1-42$ produced by beta-site amyloid cleaving enzyme 1 (BACE1) increase leptin resistance in the hypothalamus, which is associated with decreased sensitivity to exogenous leptin throughout the body and exacerbation of body weight gain in rats fed high-fat diets. Thus, countering BACE1 activity may be protective against metabolic disorders [95].

The above findings affirm cognitive impairment as a key trigger of alterations in insulin signaling in the hypothalamus. The latter region is the primary regulator of body weight via controlling food intake and peripheral metabolism [96]. Thus, cognitive impairment might lead to metabolic changes that precede the development of MS and its complications.

\section{Mild Cognitive Impairment and Metabolic Syndrome: Epidemiological Basis}

Evidence concerning the relationship of MS and its components with MCI has accumulated in the last few years to the point where grouping these disorders into a single clinical entity, the cognitive-metabolic syndrome, may be appropriate [97]. Below, we summarize clinical and epidemiological information on the MCI and MS relationship and its components.

\subsection{From Metabolic Syndrome to Cognitive Impairment}

Cardio-metabolic risk factors and MS affect cognition and increase the risk of major neurocognitive disorders [98-100]. Speed of processing, attention, and executive functions are the most frequently affected domains [101,102]. Thus, an association is often reported between risk factors, such as hyperlipidemia, T2DM, obesity, hypertension, and physical inactivity, and models of risks of cardiovascular disease (CVD) (e.g., Framingham Risk Score) with the risk of MCI and major neurocognitive disorders (Table 1) [103-106].

Strong evidence of a link between high blood pressure in middle age and poorer cognitive function in old age is available $[107,108]$. Different prospective studies in older people show that increased blood pressure is associated with worse cognitive function [109]. The risk of cognitive impairment can increase up to 2.8 times [110]. In older women, risks may increase by up to $20 \%$ [111]. Similar results were reported in individuals from Hispanic [112], Swedish [113], Asian [114], and North American communities [115,116].

Obesity, defined by a high abdominal circumference or a body mass index (BMI) $\geq 30$, is also associated with poor cognitive function $[117,118]$. Individuals with high BMI during middle age show low scores among various cognitive tests [119]. Further, long-term obesity is linked to lower cognitive performance and an increased risk of neurocognitive impairment in older people [120-122]. 
Several epidemiological studies and meta-analyses provide evidence for an effect of hyperlipidemia, hypertriacylglycerolemia, and HDL-C levels on cognitive performance in individuals with and without major neurocognitive disorders. Elevated LDL-C levels are correlated with the degree of cognitive impairment [123] and decreased episodic memory (ECM) [124]. Further, hypertriacylglycerolemia is associated with low scores in verbal tests $[124,125]$. Low concentrations of this lipoprotein are associated with poor and decreased memory in middle-aged adults [126], while in older people, low levels are associated with major neurocognitive disorders [127]. In contrast, improvement in cognitive test performance is reported for subjects over 75 years old with high HDLC [128,129], which is also associated with a significant decrease in the appearance of major neurocognitive disorders [130].

Hyperinsulinemia, glucose intolerance, and T2DM are other cardio-metabolic risk factors that recently have been associated with cognitive impairment and different major neurocognitive disorders [131]. Hyperinsulinemia and impaired glucose tolerance, both indicators of a prediabetic state and an increased risk of developing DM, are associated with cognitive dysfunction and an increased risk of developing MCI [132-135]. These premorbid states are associated with reduced long-term memory scores [136] and impaired verbal fluency [137]. Lower performance on psychomotor and memory tests is observed in diabetic individuals [138]. These lower scores correlate with an increased risk of developing cognitive impairment and MCI [139-143].

Several studies associate different elements of MS with cognitive functions. However, few studies of MS as a clinical entity and its relationship with MCI or its progression to major neurocognitive disorders are available. Roberts et al. reported a cross-sectional study in 1969 of 70 89-year-old individuals. Participants with MS showed non-amnestic MCI (naMCI) when accompanied by elevated C-reactive protein (CRP). The combination of inflammation and MS might be linked to specific subtypes of MCI [144]. Yaffe et al. conducted a longitudinal, multicenter study with 4895 women with an average age of 66.2 years. MS was associated with an increased risk of developing cognitive impairment in older women. Risk increased by an age-adjusted $23 \%$ for each increment in the number of MS components [145]. Similar findings were reported by Pal et al. [146] and Atti et al. [147], who concluded that MS is associated with an increased incidence of major neurocognitive disorders and an increased risk of progression from MCI to such disorders, respectively.

Table 1. Effects of components of MS on cognitive function, the risk of MCI, and major neurocognitive disorders.

\begin{tabular}{|c|c|c|c|}
\hline MS Component & Authors (REF) & Methodology & Results \\
\hline \multirow[t]{2}{*}{ High blood pressure } & McDonald et al. [109] & $\begin{array}{l}\text { Longitudinal cohort study of the } \\
\text { association between cognitive function } \\
\text { and BP variability in adults } \geq 65 \text { years. }\end{array}$ & $\begin{array}{l}\text { After } 5 \text { years of monitoring, diurnal } \\
\text { systolic BP variability was } \\
\text { independently associated with a greater } \\
\text { decrease in total CAMCOG (CV: } 3.205 \text {; } \\
p=0.043 \text { ) and MMSE (CV: } 3.985 ; \\
\quad p=0.020 \text { ) scores. }\end{array}$ \\
\hline & Haring et al. [111] & $\begin{array}{l}\text { Prospective study in } 6426 \text { cognitively } \\
\text { intact older women of the relationship } \\
\text { between hypertension and cognitive } \\
\text { impairment. }\end{array}$ & $\begin{array}{l}\text { Hypertension was associated with an } \\
\text { increased risk for cognitive decline } \\
\text { (HR: } 1.20 ; 95 \% \text { CI: } 1.04-1.39 ; p=0.02 \text { ). }\end{array}$ \\
\hline \multirow[t]{2}{*}{ Obesity } & Sabia et al. [121] & $\begin{array}{l}\text { Longitudinal cohort study of the } \\
\text { association between BMI and mid-age } \\
\text { cognition throughout adult life in } \\
5131 \text { individuals. }\end{array}$ & $\begin{array}{c}\text { Late midlife obesity was associated with } \\
\text { lower scores on the MMSE and on } \\
\text { memory and executive function scores } \\
\text { compared with normal-weight } \\
\text { individuals (mean difference }(95 \% \text { CI): } \\
-0.99(-1.78-0.21),-0.82(-1.57-0.08), \\
\text { and }-0.80(-1.49-0.12) \text {, respectively } \\
(p<0.05)) .\end{array}$ \\
\hline & Beydoun et al. [122] & $\begin{array}{l}\text { Meta-analysis of the association } \\
\text { between obesity and major } \\
\text { neurocognitive disorder in older adults. }\end{array}$ & $\begin{array}{l}\text { A significant U-shaped association was } \\
\text { found between BMI and major } \\
\text { neurocognitive disorder }(p=0.034), \text { with } \\
\text { an increased risk of disorder (OR ( } 95 \% \\
\text { CI): } 1.42(0.93-2.18) \text { ) and increased } \\
\text { incidence of AD (OR ( } 95 \% \text { CI): } 1.80 \\
(1.00-3.29)) \text { in obese individuals. }\end{array}$ \\
\hline
\end{tabular}


Table 1. Cont.

\begin{tabular}{|c|c|c|c|}
\hline MS Component & Authors (REF) & Methodology & Results \\
\hline \multirow[t]{2}{*}{ Dyslipidemias } & de Frias et al. [124] & $\begin{array}{c}\text { Longitudinal cohort study of the } \\
\text { association between total cholesterol, } \\
\text { triglycerides, and cognitive performance } \\
\text { in older adults. }\end{array}$ & $\begin{array}{l}\text { Hypertriglyceridemia was associated } \\
\text { with a low score on the verbal memory } \\
\text { tests }(\gamma=-2.31 ; p<0.05) \text {, while } \\
\text { hypercholesterolemia was associated } \\
\text { with a detrimental effect on facial } \\
\text { recognition test score }(\gamma=-2.13 \text {; } \\
\qquad p<0.05)\end{array}$ \\
\hline & Singh-Manoux et al. [126] & $\begin{array}{l}\text { Longitudinal cohort study of the } \\
\text { relationship between HDL-c and verbal } \\
\text { short-term memory in middle-aged } \\
\text { adults. }\end{array}$ & $\begin{array}{c}\text { After } 5 \text { years of monitoring, decreased } \\
\text { HDL-C was associated with decreased } \\
\text { verbal memory (OR }=1.61 \\
95 \% \mathrm{CI}=1.19-2.16)\end{array}$ \\
\hline \multirow{2}{*}{$\mathrm{DM}$} & Elias et al. [117] & $\begin{array}{l}\text { Longitudinal study of the effects of } \\
\text { T2DM on cognitive performance of } \\
\text { adult individuals. }\end{array}$ & $\begin{array}{l}\text { The amount of time suffering from } \\
\text { diabetes was associated with poorer } \\
\text { cognitive performance }(\beta=-0.02 ; \\
\qquad p<0.02)\end{array}$ \\
\hline & Kanaya et al. [137] & $\begin{array}{l}\text { Longitudinal cohort study of changes in } \\
\text { cognitive performance according to } \\
\text { glucose tolerance status in older adults. }\end{array}$ & $\begin{array}{l}\text { After } 4 \text { years, women with DM had a } \\
\text { 4-fold increased risk of cognitive } \\
\text { impairment (OR }(95 \% \mathrm{CI}): 4.38 \\
(1.71-11.27) ; p=0.02)\end{array}$ \\
\hline \multirow{2}{*}{ MS } & Atti et al. [147] & $\begin{array}{c}\text { Meta-analysis of the relationship } \\
\text { between MS and progression to major } \\
\text { neurocognitive disorder in individuals } \\
\text { with MCI. }\end{array}$ & $\begin{array}{l}\text { Having MS increased the risk of } \\
\text { progression from MCI to major } \\
\text { neurocognitive disorder (HR }(95 \% \mathrm{CI}) \text { : } \\
2.69(1.16-6.27) ; p<0.05)\end{array}$ \\
\hline & Pal et al. [146] & $\begin{array}{l}\text { Meta-analysis that quantified the } \\
\text { relative risk of progression from MCI to } \\
\text { major neurocognitive disorder in } \\
\text { individuals with MS. }\end{array}$ & $\begin{array}{l}\text { An increased risk of progression was } \\
\text { found in individuals with MCI and SM } \\
(\mathrm{OR}(95 \% \mathrm{CI}): 2.95(1.23-7.05) p<0.05) \text {. }\end{array}$ \\
\hline
\end{tabular}

Abbreviations: MS: metabolic syndrome; MCI: mild cognitive impairment; BP: blood pressure; CAMCOG: Cambridge Cognitive Examination; MMSE: Mini-Mental State Examination; CV: coefficient of variation; BMI: body mass index; OR: odds ratio; HR: hazard ratio; CI: confidence interval; AD: Alzheimer's disease; HDL-c: high-density lipoprotein; DM: diabetes mellitus.

The impact of MS on cognitive function is not limited to adults. There is also evidence that suggests that MS components may be detrimental in younger populations. The presence of T2DM, obesity, and hypertension in children and adolescents is associated with poorer performance in overall functioning, and declines in executive function, memory, attention, and intelligence quotient (IQ) [148-152].

Cardiovascular and metabolic risk factors are modifiable and their timely identification and consequent management could prevent $\mathrm{MCI}$ or its progression to major neurocognitive disorders [101]. Thus, lifestyle changes, including increased physical activity and implementation of healthy diets, and antihypertensive, hypolipidemic, and insulin-sensitizing drugs are important considerations for the management of premorbid state characteristics of MS (Table 2) [153].

Changes in lifestyle and physical activity positively impact cognitive function. [154,155]. Physical activity is associated with better scores on tests of executive function, processing speed, and improvement in global cognitive function. These benefits were found both in healthy older subjects and in older subjects with MCI or major neurocognitive disorders [156-159]. More studies to elucidate types of exercise, times, and intensity needed to cause a positive impact on cognition are necessary; still, $150 \mathrm{~min}$ of physical activity per week is proposed to improve the brain health of individuals with MCI [160].

Better results are obtained if physical activity is combined with a healthy diet. Supplementation with B-vitamins, folic acid, docosahexaenoic acid (DHA), eicosapentaenoic acid (EPA), and flavonoids is associated with improved cognitive performance, particularly memory, in subjects with MCI [161]. Similarly, both cognitively normal individuals and those with MCI are reported to be at less risk of developing MCI or AD if they maintain high adherence to a Mediterranean diet [162]. Similar results are associated with Mediterranean-DASH diets [163], low-carbohydrate diets (keto-diet) [164], and fish PUFA diets [165]. 
Additionally, a causal relationship between antihypertensive drugs and improved cognitive function is supported by available evidence. Antihypertensive drugs, especially calcium channel blockers and renin-angiotensin system blockers, have a protective effect on cognitive decline and decrease the risk of $\mathrm{AD}$ and neurocognitive vascular disorders in older people [166]. Similarly, treatment with antihypertensive drugs reduces the risk of major neurocognitive disorders by $9 \%$ and shows improvement in all cognitive domains, except language [167]. Longitudinal studies that included older individuals without major neurocognitive disorders who were undergoing antihypertensive therapy produced supporting results $[110,168]$.

Controlling glycemic concentrations and increasing peripheral insulin sensitivity are strategies that might positively affect cognitive function [146]. A recent meta-analysis showed that treatment with metformin or sulfonylureas is associated with a significant decrease in cognitive impairment in patients with T2DM. In contrast, the use of insulin aggravated the dysfunction [169]. Studies of metformin as monotherapy [170], or combined with vildagliptin [171], on the participants' cognitive function produced similar results. However, other studies show no association between the use of antidiabetic drugs and improvement in cognitive function [172,173]. One study linked the use of such drugs to the diagnosis of MCI [174].

Finally, unlike antihypertensive and antidiabetic drugs, hypolipidemics, such as statins, do not affect the risk of progression to $\mathrm{MCI}$ or major neurocognitive disorders of any kind $[175,176]$. Indeed, several clinical and epidemiological studies report no significant association between statin use and reduced cognitive impairment [177-180].

Table 2. Association between treatment of MS elements and MCI improvement.

\begin{tabular}{|c|c|c|c|}
\hline Therapeutic Approach & Authors (REF) & Methodology & Results \\
\hline \multirow{3}{*}{ Lifestyle changes } & Karssemeijer et al. [157] & $\begin{array}{c}\text { Meta-analysis of the effect of cognitive } \\
\text { and physical exercise intervention in } \\
\text { older adults with MCI or major } \\
\text { neurocognitive disorder. }\end{array}$ & $\begin{array}{l}\text { A positive effect of the combination of } \\
\text { physical-cognitive interventions on global } \\
\text { cognitive function was observed (MDS } \\
(95 \% \mathrm{CI})=0.32(0.17-0.47) ; p<0.05) \text {. It } \\
\text { was equally beneficial for individuals with } \\
\text { MCI (MDS }=0.39(0.15-0.63) ; p<0.05), \\
\text { and for patients with major } \\
\text { neurocognitive disorder (MDS }=0.36 \\
(0.12-0.60) ; p<0.001) .\end{array}$ \\
\hline & Zhang et al. [165] & $\begin{array}{l}\text { Meta-analysis of the association } \\
\text { between risk of cognitive impairment } \\
\text { and intake of fish and PUFAs. }\end{array}$ & $\begin{array}{c}\text { Increased fish consumption was } \\
\text { associated with decreased risk of major } \\
\text { neurocognitive disorder (RR: } 0.95 ; 95 \% \text { CI: } \\
0.90-0.99 ; p=0.042) \text {. A significant } \\
\text { curvilinear relationship was observed } \\
\text { between PUFA consumption and MCI risk } \\
\text { ( } p \text { nonlinearity }<0.001) .\end{array}$ \\
\hline & Krikorian et al. [164] & $\begin{array}{l}\text { Prospective study of the effect of a } \\
\text { ketogenic diet in older individuals } \\
\text { with MCI. }\end{array}$ & $\begin{array}{l}\text { An improvement in verbal memory } \\
\text { performance was observed in patients on } \\
\text { a low-carbohydrate diet }(p=0.001) \text {. } \\
\text { Memory performance was positively } \\
\text { correlated with ketone levels }(p=0.04) \text {. }\end{array}$ \\
\hline \multirow{2}{*}{ Antihypertensives } & Tzourio et al. [110] & $\begin{array}{l}\text { A longitudinal study of the effect of } \\
\text { antihypertensive drugs on the risk of } \\
\text { cognitive decline in older individuals. }\end{array}$ & $\begin{array}{l}\text { The risk of cognitive impairment was } \\
\text { higher in untreated subjects (OR }=6.0 \\
(95 \% \text { CI: } 2.4-15.0)) \text {, compared with } \\
\text { subjects treated with antihypertensives } \\
(\text { OR }=1.3(95 \% \text { CI: } 0.3-4.9))\end{array}$ \\
\hline & Guo et al. [168] & $\begin{array}{l}\text { Prospective study that evaluated } \\
\text { whether the use of antihypertensives } \\
\text { affected the appearance and } \\
\text { progression of major neurocognitive } \\
\text { disorders in older adults. }\end{array}$ & $\begin{array}{l}\text { The risk of major neurocognitive disorder } \\
\text { was reduced in subjects receiving } \\
\text { antihypertensive treatment and without } \\
\text { major neurocognitive disorder at the } \\
\text { beginning of the study (RR }=0.7 \\
\text { (95\% CI: } 0.6-1.0) ; p=0.03) .\end{array}$ \\
\hline
\end{tabular}


Table 2. Cont.

\begin{tabular}{|c|c|c|c|}
\hline Therapeutic Approach & Authors (REF) & Methodology & Results \\
\hline \multirow[t]{2}{*}{ Antidiabetics } & Ng et al. [170] & $\begin{array}{l}\text { Longitudinal study of the protective } \\
\text { effect of metformin on the cognitive } \\
\text { performance of older adults. }\end{array}$ & $\begin{array}{l}\text { Use of metformin showed an inverse } \\
\text { association with cognitive impairment } \\
(\mathrm{OR}=0.49 \text { (CI 95\%: 0.25-0.95); } p<0.05) \text {, } \\
\text { and was associated with a low risk of } \\
\text { cognitive impairment after } 6 \text { years of use } \\
(\mathrm{OR}=0.27 \text { (CI 95\%: } 0.12-0.60) ; p<0.05) \text {. }\end{array}$ \\
\hline & Borzì et al. [171] & $\begin{array}{l}\text { Retrospective study of the effect of } \\
\text { vildagliptin on cognitive function in } \\
\text { older diabetic adults with MCI. }\end{array}$ & $\begin{array}{l}\text { The use of metformin as monotherapy or } \\
\text { in combination with vildagliptin was } \\
\text { associated with a significant reduction in } \\
\text { MMSE score }(p<0.001) \text {. }\end{array}$ \\
\hline \multirow[b]{2}{*}{ Hypolipidemics } & Bosch et al. [177] & $\begin{array}{l}\text { Clinical trial on the effect of } \\
\text { rosuvastatin in reducing cognitive } \\
\text { impairment in older adults. }\end{array}$ & $\begin{array}{l}\text { The mean difference in DSST score } \\
\text { between rosuvastatin vs. placebo was } \\
-0.54(95 \% \text { CI: }-1.88-0.80) ; p<0.05 \text {. }\end{array}$ \\
\hline & Bettermann et al. [178] & $\begin{array}{l}\text { Clinical trial on the impact of statin } \\
\text { use on delaying cognitive decline in } \\
\text { patients with and without MCI. }\end{array}$ & $\begin{array}{l}\text { Statins were associated with a decreased } \\
\text { risk for increased neurocognitive } \\
\text { impairment from all causes in patients } \\
\text { who did not have } \mathrm{MCI} \text { at the beginning of } \\
\text { the study (HR }=0.79 \text { ( } 95 \% \mathrm{CI}: 0.65-0.96) \\
p=0.021) \text {. In subjects with MCI, these } \\
\text { protective effects were not observed. }\end{array}$ \\
\hline
\end{tabular}

Abbreviations: MS: metabolic syndrome; MCI: mild cognitive impairment; SMD: standardized mean difference scores; PUFAs: polyunsaturated fatty acids; MMSE: Mini-Mental State Examination; CV: coefficient of variation; OR: odds ratio; RR: relative risk; HR: hazard ratio; CI: confidence interval; DSST: Digit Symbol Substitution Test.

\subsection{Exploring the Reverse Relationship -From Cognitive Disorder to Metabolic Syndrome}

Epidemiological studies suggest the inverse relationship. MCI has been assessed as a contributor to the development of MS (Table 3). In a cross-sectional study of 3312 male and female participants aged 70 years and older in Japan, a higher prevalence of MS was observed in subjects with naMCI than in those with normal cognition. Moreover, women with naMCI had high blood pressure and high glucose levels more often, while men with naMCI showed only a higher frequency of high glucose levels compared with the control group. However, a causal relationship between the two could not be determined from this cross-sectional study [181]. Clinical evidence is still scarce and has focused more on specific components of MS, such as insulin/glucose alterations and T2DM, than on MS as an entity.

Alterations in insulin signaling have been reported in postmortem studies in brains from individuals with AD [182,183], as well as in patients with AD in clinical studies of plasma hyperinsulinemia and reductions in insulin levels in the CSF. These changes worsen as the disease progresses [184]. Animal models produce similar results [88,185]. Accordingly, Janson et al. used the Mayo Clinic Alzheimer's Disease Patient Registry to show a higher incidence of both T2DM and IR in $80 \%$ of AD patients. A greater increase in fasting plasma glucose (FPG) with age compared with the control group was also observed. $\mathrm{AD}$ patients might thus be at greater risk of developing a diabetic phenotype and suffering from T2DM [186].

Similarly, a longitudinal study using data from the Lothian Birth Cohort of 1936 (LBC1936) examined parameters, such as cognitive changes and glucose levels. This cohort consists of 1091 initially healthy individuals born in 1936. Individuals were assessed using glycosylated hemoglobin (HbA1c) data for four ages-70, 73, 76, and 79 years. Lower cognitive function at 70 years was associated with increased $\mathrm{HbA} 1 \mathrm{c}$ in the following decade. Cognitive dysfunction is thus negatively correlated with increases in $\mathrm{HbA} 1 \mathrm{c}$. Maintaining high cognitive function could be a protective factor for the development of hyperglycemia and T2DM [187].

Likewise, Peng et al. initially conducted a cross-sectional study in 2126 participants, including 1063 patients recently diagnosed with T2DM and 1063 patients with standard glucose tolerance. Individuals with higher plasma concentrations of both $A \beta 40$ and $A \beta 42$ were more likely to have T2DM compared to subjects with the lowest concentrations [188]. In a follow-up study, the authors examined Tongii-Ezhou Cohort (TJEZ) data prospectively. One hundred and twenty-one individuals with T2DM and 242 healthy individuals were 
included. The same association was found, where the probability of T2DM was higher with higher plasma concentrations of $A \beta, 3.79$ (95\% CI 1.81-7.94) for $A \beta 40$ and $2.88(95 \%$ CI 1.44-5.75) for $A \beta 42$. The authors conclude that a positive association exists between $A \beta$ and the risk of acquiring T2DM [188].

Table 3. Effect of cognitive dysfunction and suffering from MS or MS components.

\begin{tabular}{|c|c|c|}
\hline Author (REF) & Methodology & Results \\
\hline Janson et al. [186] & $\begin{array}{l}\text { Longitudinal study where prevalence of } \\
\text { T2DM in patients with AD was } \\
\text { evaluated, along with the association } \\
\text { between FPG and aging in these patients. }\end{array}$ & $\begin{array}{l}\text { The prevalence of T2DM ( } 34.6 \text { vs. } 18.1 \% \text {; } \\
p<0.05 \text { ) and IFG ( } 46.2 \text { vs. } 23.8 \% ; p<0.01) \\
\text { was higher in the AD group vs. the control } \\
\text { group. A greater increase was seen in FPG } \\
\text { per year in the AD group } \\
\qquad\left(0.83 \text { vs. } 0.57 \mathrm{mg} / \mathrm{dL}^{-1} ; p<0.01\right)\end{array}$ \\
\hline Bae et al. [181] & $\begin{array}{l}\text { Cross-sectional study of the prevalence of } \\
\text { MS by type of MCI in } 3312 \text { older adults } \\
\text { and differences related to sex. }\end{array}$ & $\begin{array}{c}\text { The prevalence of MS was higher in } \\
\text { participants with naMCI (men: } p=0.030 \text {; } \\
\text { women: } p=0.040 \text { ) and the risk of MS was } \\
\text { higher in men }(\mathrm{OR}=2.45 ; 95 \% \mathrm{CI}: 1.13-5.32) \\
\text { than in women (OR }=1.94 ; 95 \% \mathrm{CI}: 1.12-3.39) \\
\text { compared with participants with } \\
\text { normal cognition. }\end{array}$ \\
\hline Altschul et al. [187] & $\begin{array}{l}\text { Longitudinal cohort study of the } \\
\text { association between cognitive function, } \\
\mathrm{HbA1c} \text {, and other variables in early and } \\
\text { late life in } 1091 \text { adults. }\end{array}$ & $\begin{array}{l}\text { High cognitive function at age } 11 \text { predicted } \\
\text { low HbA1c levels at age } 70(p<0.001) \text {. } \\
\text { Additionally, high cognitive function at age } \\
70 \text { was associated with a smaller increase in } \\
\text { HbA1c levels between age } 70 \text { and } 79 \\
\qquad(p<0.001) \text {. }\end{array}$ \\
\hline Peng et al. [188]. & $\begin{array}{c}\text { Study comparing } 1063 \text { newly T2DM } \\
\text { diagnosed individuals with } 1063 \text { control } \\
\text { individuals for an association between } \\
\text { plasma concentrations of A } \beta 40 \text { and A } \beta 42 \\
\text { with risk of T2DM. }\end{array}$ & $\begin{array}{c}\text { The risk of T2DM was higher in individuals } \\
\text { with the highest concentrations of } A \beta 40 \text { and } \\
\text { A } \beta 42(\mathrm{OR}=2.96(95 \% \mathrm{CI}: 2.06-4.25)) \\
\text { compared with subjects with the lowest } \\
\text { concentrations of } \mathrm{A} \beta \text {. }\end{array}$ \\
\hline Peng et al. [188]. & $\begin{array}{l}\text { Prospective study of the association } \\
\text { between plasma concentrations of } A \beta 40 \\
\text { and } A \beta 42 \text { with risk of T2DM. }\end{array}$ & $\begin{array}{c}\text { A higher risk of T2DM was found in } \\
\text { individuals with concentrations greater than } \\
\text { that of } \mathrm{A} \beta(\mathrm{OR}=3.79(95 \% \mathrm{CI}: 1.81-7.94)) \text { for } \\
\mathrm{A} \beta 40 \text { and }(\mathrm{OR}=2.88(95 \% \mathrm{CI}: 1.44-5.75)) \\
\text { for } \mathrm{A} \beta 42 .\end{array}$ \\
\hline
\end{tabular}

Abbreviations: T2DM: diabetes mellitus type 2; HbA1c: glycated hemoglobin; FPG: fasting plasmatic glucose; IFG impaired fasting glucose; MCI: mild cognitive impairment; naMCI: non-amnestic mild cognitive impairment; A $\beta$ : amyloid-beta; OR: odds ratio; CI: confidence interval.

These findings imply that therapeutic intervention aimed at MCI, especially AD, could be beneficial for treating MS and its components (Table 4). A drug approved for the treatment of moderate-to-severe AD is memantine, an NMDA receptor antagonist that reduces the accumulation of $A \beta$ in $A D$ patients [189]. Ettcheto et al. analyzed the effects of memantine in rats with model AD that were fed a high-fat diet. After 12 weeks of treatment with $30 \mathrm{mg} / \mathrm{kg}$ memantine, improvement of peripheral metabolic parameters, such as IR, was observed [190].

Similarly, Ahmed et al. investigated piracetam and memantine in the treatment of T2DM in 120 individuals. Piracetam is used to improve memory and brain function. Diabetic patients with AD treated with either drug showed a significant reduction in diabetic markers (GPA, $\mathrm{HbA} 1 \mathrm{c} \%$, and insulin levels) compared to a symptomatic control group. Thus, agents used to treat MCI demonstrate a therapeutic potential for the treatment of metabolic disorder [191].

Another therapeutic strategy is based on reducing the activity of enzymes that promote the formation of $A \beta$, such as BACE1. The metabolic role of BACE1 is not fully understood, though loss of BACE1 in transgenic rats leads to increased sensitivity to insulin and 
decreased body weight [192]. Its mechanisms of action may involve leptin signaling and thermogenesis [95]. These results were extrapolated in a randomized clinical trial (RCT). Patients with AD treated with lanabecestat, a BACE1 inhibitor, showed greater weight loss than a placebo group after 104 weeks of treatment [193].

Additionally, immunotherapy against $A \beta$ is used to improve insulin sensitivity and plasma glucose levels. Zhang et al. used an APP/PS1 EA rat model with increased plasma levels of $A \beta 40 / 42$. Animals exhibited altered glucose/insulin tolerance and liver insulin signaling. After nine months of intraperitoneal injections of antibodies against $A \beta$, an improvement was observed in insulin sensitivity. Hepatic signaling of JAK2/STAT3/SOCS1 compared to the control group was concurrently attenuated. Thus, neutralization of A $\beta$ attenuates hyperglycemia and IR in vivo [194].

Table 4. Summary of preclinical and clinical studies exploring treatment of SM with anti-Alzheimer's drugs.

\begin{tabular}{|c|c|c|c|}
\hline Author (REF) & Treatment & Methodology & Results \\
\hline Ettcheto et al. [190] & Memantine & $\begin{array}{l}\text { Preclinical study of the effects of } \\
\text { MEM on learning and memory } \\
\text { impairment in rats with familial AD } \\
\text { and HFD-induced insulin resistance. }\end{array}$ & $\begin{array}{c}\text { MEM prevented body weight } \\
\text { increase in HFD-fed mice with } \\
\text { APP /PS1 }(p<0.001) \text {. Hepatic IR } \\
\text { protein levels showed a significant } \\
\text { increase in APP/PS1 MEM mice } \\
\text { compared to nontreated controls } \\
(p<0.05), \text { improving insulin function } \\
\text { in the liver. }\end{array}$ \\
\hline Zhang et al. [194] & $\begin{array}{c}\text { Anti- } A \beta \\
\text { Immunotherapy }\end{array}$ & $\begin{array}{l}\text { Preclinical study of the effects of } \\
\text { intraperitoneal injections of anti-A } \beta \\
\text { antibodies in APP/PS1 rats on } \\
\text { glucose metabolism. }\end{array}$ & $\begin{array}{c}\text { After } 9 \text { months of treatment, } \\
\text { neutralization of } \mathrm{A} \beta \text { reduced fasting } \\
\text { blood glucose level }(p<0.001), \\
\text { improved insulin sensitivity } \\
(p<0.05), \text { and inhibited hepatic } \\
\text { JAK2/STAT3/SOCS1 signaling } \\
(p<0.05) \text { in APP/PS1 AD model rats. }\end{array}$ \\
\hline Wessels et al. [193] & Lanabecestat & $\begin{array}{l}\text { RCT that assessed whether } \\
\text { lanabecestat slows the progression of } \\
\mathrm{AD} \text { compared with placebo in } \\
\text { patients with early AD (mild } \\
\text { cognitive impairment) and mild } \\
\text { AD dementia. }\end{array}$ & $\begin{array}{l}\text { Even though treatment with } \\
\text { lanabecestat did not slow cognitive } \\
\text { decline, patients who completed } \\
\text { week } 104 \text { had a mean (SD) weight } \\
\text { loss of } 0 \text { (4.7) } \mathrm{kg} \text { for placebo, }-0.8 \\
\text { (4.6) kg for patients treated with } \\
20 \mathrm{mg} \text { lanabecestat, and }-1.9(5.2) \mathrm{kg} \\
\text { for those treated with } 50 \mathrm{mg} \text {. }\end{array}$ \\
\hline Ahmed et al. [191] & MemantinePiracetam & $\begin{array}{l}\text { Clinical study of the effect of } \\
\text { piracetam and memantine on } \\
\text { diabetes mellitus. }\end{array}$ & $\begin{array}{l}\text { A significant decrease in all diabetic } \\
\text { markers (FPG, HbA1c\%, and insulin } \\
\text { levels) in the diabetic and } \\
\text { Alzheimer's patients was observed } \\
\text { after treatment with memantine or } \\
\text { piracetam compared to diabetic and } \\
\text { Alzheimer's patients with } \\
\text { symptomatic treatment }(p<0.05) \text {. }\end{array}$ \\
\hline
\end{tabular}

Abbreviations: MEM: memantin; AD: Alzheimer's disease; HFD: high-fat diet; A $\beta$ : amyloid-beta; RCT: randomized clinical trial; FPG: fasting plasmatic glucose; HbA1c: glycated hemoglobin.

Numerous epidemiological and clinical studies and meta-analyses provide evidence that MS and its components have a substantial impact on the development of MCI. However, the inverse relationship, where MCI contributes to MS risk, is feasible, though some studies report the lack of association between these clinical entities [195-198]. A causal relationship between MS and MCI has yet to be conclusively identified. 


\section{Conclusions}

The current epidemic of metabolic disorders, framed in what we term MS, increases in a society with unhealthy lifestyles, and many aspects of this condition are still unknown. Research on MS generates a constant stream of new information and a flood of debate on whether this pathology exists, its components, and the pathophysiological mechanisms that produce it.

Recently, a two-way relationship between MS and brain disorders, such as MCI and $\mathrm{AD}$, has been observed, but without clarity regarding which phenomenon occurs first and which pathophysiological pathways are involved. Contrasting findings could be attributed to factors inherent in the complex nature of MS and MCI. Both disorders are multifactorial and display disparity in clinical manifestations. Further, research methodology is heterogeneous, reflecting the variability in criteria used to define MS, methods used for evaluating cognitive function, study design, and the presence of confounding factors. The latter factors might be varying characteristics of the populations studied, such as age, sex, race, educational status, socioeconomic status, and health-disease status. Large-scale studies with adequate power and longer follow-up periods will be necessary to establish a direct and accurate causal relationship between MS and MCI pathologies.

Author Contributions: Conceptualization: M.R., M.C.-C., E.D.-C. and V.B.; investigation: S.D.A.; M.R., M.C.-C., D.P., H.P. and M.N.; writing-original draft: M.G.-D.; S.D.A.; M.R., D.P., H.P. and M.N.; writing-review and editing: M.R., M.C.-C., M.C., L.A., R.A., J.S., V.B., R.O. and E.D.-C.; funding acquisition: V.B., E.D.-C., M.G.-D. and M.C. All authors have read and agreed to the published version of the manuscript.

Funding: This work was supported by research grant no. 2021810819 from La Universidad Simón Bolívar, Cúcuta, Colombia, and CC-0437-10-21-09-10 from Consejo de Desarrollo Científico, Humanístico y Tecnológico (CONDES), University of Zulia, and the research grant no. FZ-0058-2007 from Fundacite-Zulia.

Acknowledgments: This paper is derived from the doctoral dissertation work of Edgar Díaz-Camargo, student of the doctorate in Psychology at the Universidad Simón Bolívar.

Conflicts of Interest: The authors have no conflict of interest to disclose.

\section{References}

1. Hennekens, C.H.; Andreotti, F. Leading Avoidable Cause of Premature Deaths Worldwide: Case for Obesity. Am. J. Med. 2013, 126, 97-98. [CrossRef] [PubMed]

2. Bermúdez, V.; Añez, R.; Salazar, J.J.; Sanchez, H.; Castellanos, B.; Bello, L.; Villalobos, M. Comportamiento Epidemiológico del síndrome metabólico en el municipio Maracaibo-Venezuela. Síndrome Cardiometabólico 2013, 3, 31-42.

3. Alberti, K.G.M.M.; Eckel, R.H.; Grundy, S.M.; Zimmet, P.Z.; Cleeman, J.I.; Donato, K.A.; Smith, S.C., Jr. Harmonizing the metabolic syndrome: A joint interim statement of the International Diabetes Federation Task Force on Epidemiology and Prevention; National Heart, Lung, and Blood Institute; American Heart Association; World Heart Federation; International Atherosclerosis Society; and International Association for the Study of Obesity. Circulation 2009, 120, 1640-1645.

4. Morales Aguilar, R.; Lastre-Amell, G.; Pardo Vásquez, A. Estilos de vida relacionados con factores de riesgo cardiovascular. Arch. Venez. Farmacol. Ter. 2018, 38, 9.

5. Mente, A.; Yusuf, S.; Islam, S.; McQueen, M.J.; Tanomsup, S.; Onen, C.L.; Rangarajan, S.; Gerstein, H.C.; Anand, S.S. Metabolic syndrome and risk of acute myocardial infarction a case-control study of 26,903 subjects from 52 countries. J. Am. Coll. Cardiol. 2010, 55, 2390-2398. [CrossRef]

6. Espinoza Diaz, C.I.E.; Morocho Zambrano, A.A.; Pesantez Placencia, L.F.; Toala Guerrero, J.E.; Bravo Rey, P.J.; Garavito Martinez, A.M.; Carbo Tapia, A.D.; García Vargas, J.J. Prevalencia de síndrome metabólico y factores asociados en adultos mayores de la parroquia de Baños, Cuenca. Arch. Venez. Farmacol. Ter. 2018, 39, 6.

7. Kerekes, G.; Nurmohamed, M.T.; González-Gay, M.A.; Seres, I.; Paragh, G.; Kardos, Z.; Baráth, Z.; Tamási, L.; Soltész, P.; Szekanecz, Z. Rheumatoid arthritis and metabolic syndrome. Nat. Rev. Rheumatol. 2014, 10, 691-696. [CrossRef] [PubMed]

8. Uzunlulu, M.; Caklili, O.T.; Oguz, A. Association between Metabolic Syndrome and Cancer. Ann. Nutr. Metab. 2016, 68, 173-179. [CrossRef]

9. Bangen, K.J.; Armstrong, N.M.; Au, R.; Gross, A.L. Metabolic Syndrome and Cognitive Trajectories in the Framingham Offspring Study. J. Alzheimer's Dis. 2019, 71, 931-943. [CrossRef] 
10. Laws, S.M.; Gaskin, S.; Woodfield, A.; Srikanth, V.; Bruce, D.; Fraser, P.E.; Porter, T.; Newsholme, P.; Wijesekara, N.; Burnham, S.; et al. Insulin resistance is associated with reductions in specific cognitive domains and increases in CSF tau in cognitively normal adults. Sci. Rep. 2017, 7, 1-11. [CrossRef]

11. Petersen, R.C.; Roberts, R.O.; Knopman, D.S.; Boeve, B.F.; Geda, Y.E.; Ivnik, R.J.; Smith, G.E.; Jack, C.R., Jr. Mild cognitive impairment: Ten years later. Arch. Neurol. 2009, 66, 1447-1455. [CrossRef] [PubMed]

12. Sanford, A.M. Mild Cognitive Impairment. Clin. Geriatr. Med. 2017, 33, 325-337. [CrossRef] [PubMed]

13. Vanegas, H. Buscando las bases moleculares de la enfermedad de Alzheimer. Gac. Médica Caracas 2017, $125,4-11$.

14. Biessels, G.J.; Despa, F. Cognitive decline and dementia in diabetes mellitus: Mechanisms and clinical implications. Nat. Rev. Endocrinol. 2018, 14, 591-604. [CrossRef] [PubMed]

15. Arnold, S.E.; Arvanitakis, Z.; Macauley-Rambach, S.L.; Koenig, A.M.; Wang, H.-Y.; Ahima, R.S.; Craft, S.; Gandy, S.; Buettner, C.; Stoeckel, L.E.; et al. Brain insulin resistance in type 2 diabetes and Alzheimer disease: Concepts and conundrums. Nat. Rev. Neurol. 2018, 14, 168-181. [CrossRef]

16. Kylin, E. Hypertonie and Zuckerkrankheit. Zent. Inn. Med. 1921, 42, 873-877.

17. Marañon, G. Über Hypertonie and Zuckerkrankheit. Zent. Inn. Med. 1922, 43, 169-176.

18. Hanefeld, M.; Leonhardt, W. Das Metabolische Syndrom. Dt Gesundh Wesen. 1981, 36, 545-551. [CrossRef]

19. Reaven, G.M. Banting lecture Role of insulin resistance in human disease. Diabetes 1988, 37, 1595-1607. [CrossRef]

20. Reaven, G.M. Why Syndrome X? From Harold Himsworth to the Insulin Resistance Syndrome. Cell Metab. 2005, 1, 9-14. [CrossRef]

21. Randle, P.; Garland, P.; Hales, C.; Newsholme, E. The glucose fatty-acid cycle its role in insulin sensitivity and the metabolic disturbances of diabetes mellitus. Lancet 1963, 281, 785-789. [CrossRef]

22. DeFronzo, R.A.; Ferrannini, E. Insulin resistance. A multifaceted syndrome responsible for NIDDM, obesity, hypertension, dyslipidemia, and atherosclerotic cardiovascular disease. Diabetes Care 1991, 14, 173-194. [CrossRef] [PubMed]

23. Alberti, K.G.; Zimmet, P.Z. Definition, diagnosis and classification of diabetes mellitus and its complications. Part 1: Diagnosis and classification of diabetes mellitus provisional report of a WHO consultation. Diabet. Med. J. Br. Diabet. Assoc. 1998, 15, 539-553. [CrossRef]

24. Balkau, B.; Charles, M.A. Comment on the provisional report from the WHO consultation. Diabet. Med. 1999, 16, 442-443. [CrossRef]

25. Reaven, G.M. The metabolic syndrome: Is this diagnosis necessary? Am. J. Clin. Nutr. 2006, 83, 1237-1247. [CrossRef]

26. Einhorn, D.; Reaven, G.M.; Cobin, R.H.; Ford, E.; Ganda, O.P.; Handelsman, Y.; Hellman, R.; Jellinger, P.S.; Kendall, D.; Krauss, R.M.; et al. American College of Endocrinology position statement on the insulin resistance syndrome. Endocr. Pract. 2003, 9 , 237-252. [CrossRef] [PubMed]

27. Alberti, K.G.M.M.; Zimmet, P.; Shaw, J. Metabolic syndrome-a new world-wide definition. A Consensus Statement from the International Diabetes Federation. Diabet. Med. 2006, 23, 469-480. [CrossRef]

28. Alegría Ezquerra, E.; Castellano Vázquez, J.M.; Alegría Barrero, A. Obesity, metabolic syndrome and diabetes: Cardiovascular implications and therapy. Rev. Esp. Cardiol. 2008, 61, 752-764. [CrossRef]

29. Gunczler, P. Síndrome de resistencia a la insulina en niños y adolescentes. Gac. Médica. Caracas 2006, 114, 99-103.

30. Després, J.-P.; Lemieux, I.; Bergeron, J.; Pibarot, P.; Mathieu, P.; LaRose, E.; Rodés-Cabau, J.; Bertrand, O.F.; Poirier, P. Abdominal Obesity and the Metabolic Syndrome: Contribution to Global Cardiometabolic Risk. Arter. Thromb. Vasc. Biol. 2008, 28, 1039-1049. [CrossRef]

31. Jais, A.; Brüning, J.C. Hypothalamic inflammation in obesity and metabolic disease. J. Clin. Investig. 2017, 127, 24-32. [CrossRef]

32. Rönnemaa, E.; Zethelius, B.; Sundelöf, J.; Sundström, J.; Degerman-Gunnarsson, M.; Berne, C.; Lannfelt, L.; Kilander, L. Impaired insulin secretion increases the risk of Alzheimer disease. Neurology 2008, 71, 1065-1071. [CrossRef]

33. Cohen, A.D.; Klunk, W.E. Early detection of Alzheimer's disease using PiB and FDG PET. Neurobiol. Dis. 2014, 72, 117-122. [CrossRef]

34. Segura, B.; Jurado, M.Á.; Freixenet, N.; Albuin, C.; Muniesa, J.; Junque, C. Mental slowness and executive dysfunctions in patients with metabolic syndrome. Neurosci. Lett. 2009, 462, 49-53. [CrossRef]

35. Narváez López, E.J.; Bravo Peláez, J.A.; Almeida Lozano, K.A.; Alvarez Rivera, C.G.; Mendoza Argandoña, C.A.; Morales Sánchez, A.M.; Godos Rivera, D.T.; Del Salto Ocaña, T.E.; Catota Camacho, M.M. Implicación de polimorfismos de apolipoproteína en la fisiopatología de la ateroesclerosis y enfermedad de Alzheimer. Rev. Latinoam. Hipertens. 2018, 13, 6.

36. Anstey, K.J.; Cherbuin, N.; Budge, M.; Young, J. Body mass index in midlife and late-life as a risk factor for dementia: A me-ta-analysis of prospective studies. Obes. Rev. Off. J. Int. Assoc. Study Obes. 2011, 12, 426-437. [CrossRef]

37. Grillo, C.; Woodruff, J.L.; Macht, V.A.; Reagan, L.P. Insulin resistance and hippocampal dysfunction: Disentangling peripheral and brain causes from consequences. Exp. Neurol. 2019, 318, 71-77. [CrossRef]

38. Lindqvist, A.; Mohapel, P.; Bouter, B.; Frielingsdorf, H.; Pizzo, D.; Brundin, P.; Erlanson-Albertsson, C. High-fat diet impairs hippocampal neurogenesis in male rats. Eur. J. Neurol. 2006, 13, 1385-1388. [CrossRef]

39. Karimi, S.A.; Salehi, I.; Komaki, A.; Sarihi, A.; Zarei, M.; Shahidi, S. Effect of high-fat diet and antioxidants on hippocampal long-term potentiation in rats: An in vivo study. Brain Res. 2013, 1539, 1-6. [CrossRef] [PubMed]

40. Nguyen, T.T.; Ta, Q.T.H.; Nguyen, T.T.D.; Le, T.T.; Vo, V.G. Role of Insulin Resistance in the Alzheimer's Disease Progression. Neurochem. Res. 2020, 45, 1481-1491. [CrossRef] [PubMed] 
41. Vander Zanden, C.M.; Chi, E.Y. Passive immunotherapies targeting amyloid beta and Tau oligomers in Alzheimer's disease. J. Pharm. Sci. 2020, 109, 68-73. [CrossRef]

42. Hurrle, S.; Hsu, W.H. The etiology of oxidative stress in insulin resistance. Biomed. J. 2017, 40, 257-262. [CrossRef] [PubMed]

43. Kinney, J.W.; Bemiller, S.M.; Murtishaw, A.S.; Leisgang, A.M.; Salazar, A.M.; Lamb, B.T. Inflammation as a central mechanism in Alz-heimer's disease. Alzheimers Dement. Transl. Res. Clin. Interv. 2018, 4, 575-590. [CrossRef]

44. Walker, J.M.; Harrison, F.E. Shared Neuropathological Characteristics of Obesity, Type 2 Diabetes and Alzheimer's Disease: Impacts on Cognitive Decline. Nutrients 2015, 7, 7332-7357. [CrossRef]

45. Shiiki, T.; Ohtsuki, S.; Kurihara, A.; Naganuma, H.; Nishimura, K.; Tachikawa, M.; Hosoya, K.; Terasaki, T. Brain insulin impairs amyloid-beta(1-40) clearance from the brain. J. Neurosci. Off. J. Soc. Neurosci. 2004, 24, 9632-9637. [CrossRef]

46. Liu, Z.; Patil, I.Y.; Jiang, T.; Sancheti, H.; Walsh, J.P.; Stiles, B.L.; Yin, F.; Cadenas, E. High-Fat Diet Induces Hepatic Insulin Resistance and Impairment of Synaptic Plasticity. PLoS ONE 2015, 10, e0128274. [CrossRef]

47. Zeng, Y.; Zhang, L.; Hu, Z. Cerebral insulin, insulin signaling pathway, and brain angiogenesis. Neurol. Sci. 2016, 37, 9-16. [CrossRef]

48. Liang, C.; Lam, P.; Martinez, S.; Mukherjee, J. Development of [18F]FAZIN3 for PET imaging of neurofibrillary tangles in Alz-heimer's Disease. J. Nucl. Med. 2020, 61, 1032.

49. Benedict, C.; Grillo, C. Insulin Resistance as a Therapeutic Target in the Treatment of Alzheimer's Disease: A State-of-the-Art Review. Front. Neurosci. 2018, 12, 215. [CrossRef]

50. Yarchoan, M.; Toledo, J.; Lee, E.B.; Arvanitakis, Z.; Kazi, H.; Han, L.-Y.; Louneva, N.; Lee, V.M.-Y.; Kim, S.F.; Trojanowski, J.Q.; et al. Abnormal serine phosphorylation of insulin receptor substrate 1 is associated with tau pathology in Alzheimer's disease and tauopathies. Acta Neuropathol. 2014, 128, 679-689. [CrossRef]

51. Starks, E.J.; Patrick O'Grady, J.; Hoscheidt, S.M.; Racine, A.M.; Carlsson, C.M.; Zetterberg, H.; Blennow, K.; Okonkwo, O.C.; Puglielli, L.; Asthana, S.; et al. Insulin resistance is associated with higher cerebrospinal fluid Tau levels in asymptomatic APOE \&4 Carriers. J. Alzheimers Dis. JAD 2015, 46, 525-533. [CrossRef]

52. Kim, B.; Sullivan, K.A.; Backus, C.; Feldman, E.L. Cortical Neurons Develop Insulin Resistance and Blunted Akt Signaling: A Potential Mechanism Contributing to Enhanced Ischemic Injury in Diabetes. Antioxidants Redox Signal. 2011, 14, 1829-1839. [CrossRef]

53. Zhang, Y.; Huang, N.-Q.; Yan, F.; Jin, H.; Zhou, S.-Y.; Shi, J.-S.; Jin, F. Diabetes mellitus and Alzheimer's disease: GSK-3 $\beta$ as a potential link. Behav. Brain Res. 2018, 339, 57-65. [CrossRef]

54. Esposito, G.; Scuderi, C.; Lu, J.; Savani, C.; De Filippis, D.; Iuvone, T.; Steardo, L., Jr.; Sheen, V.; Steardo, L. S100B induces tau protein hyperphosphorylation via Dickopff-1 up-regulation and disrupts the Wnt pathway in human neural stem cells. J. Cell. Mol. Med. 2008, 12, 914-927. [CrossRef]

55. van der Harg, J.M.; Eggels, L.; Bangel, F.N.; Ruigrok, S.R.; Zwart, R.; Hoozemans, J.J.M.; la Fleur, S.E.; Scheper, W. Insulin deficiency results in reversible protein kinase A activation and tau phosphorylation. Neurobiol. Dis. 2017, 103, 163-173. [CrossRef]

56. Gratuze, M.; Julien, J.; Petry, F.R.; Morin, F.; Planel, E. Insulin deprivation induces PP2A inhibition and tau hyperphosphorylation in hTau mice, a model of Alzheimer's disease-like tau pathology. Sci. Rep. 2017, 7, srep46359. [CrossRef]

57. Kins, S.; Crameri, A.; Evans, D.R.; Hemmings, B.A.; Nitsch, R.M.; Gotz, J. Reduced protein phosphatase 2A activity induces hyper-phosphorylation and altered compartmentalization of tau in transgenic mice. J. Biol. Chem. 2001, 276, 38193-38200. [CrossRef]

58. Planel, E.; Tatebayashi, Y.; Miyasaka, T.; Liu, L.; Wang, L.; Herman, M.; Yu, W.H.; Luchsinger, J.A.; Wadzinski, B.; Duff, K.E.; et al. Insulin dysfunction induces in vivo tau hyperphos-phorylation through distinct mechanisms. J. Neurosci. Off. J. Soc. Neurosci. 2007, 27, 13635-13648. [CrossRef]

59. Zilka, N.; Filipcik, P.; Koson, P.; Fialova, L.; Skrabana, R.; Zilkova, M.; Rolkova, G.P.; Kontsekova, E.; Novak, M. Truncated tau from sporadic Alzheimer's disease suffices to drive neurofibrillary degeneration in vivo. FEBS Lett. 2006, 580, 3582-3588. [CrossRef]

60. Kim, B.; Backus, C.; Oh, S.; Hayes, J.M.; Feldman, E.L. Increased Tau Phosphorylation and Cleavage in Mouse Models of Type 1 and Type 2 Diabetes. Endocrinology 2009, 150, 5294-5301. [CrossRef]

61. Kim, B.; Backus, C.; Oh, S.; Feldman, E.L. Hyperglycemia-Induced Tau Cleavage in vitro and in vivo: A Possible Link Between Diabetes and Alzheimer's Disease. J. Alzheimer's Dis. 2013, 34, 727-739. [CrossRef]

62. Forny-Germano, L.; De Felice, F.G.; Vieira, M.N.D.N. The Role of Leptin and Adiponectin in Obesity-Associated Cognitive Decline and Alzheimer's Disease. Front. Neurosci. 2019, 12, 1027. [CrossRef]

63. Suyama, S.; Maekawa, F.; Maejima, Y.; Kubota, N.; Kadowaki, T.; Yada, T. Glucose level determines excitatory or inhibitory effects of adiponectin on arcuate POMC neuron activity and feeding. Sci. Rep. 2016, 6, 30796. [CrossRef]

64. Friedman, J. The long road to leptin. J. Clin. Investig. 2016, 126, 4727-4734. [CrossRef]

65. Bouret, S.G. Neurodevelopmental actions of leptin. Brain Res. 2010, 1350, 2-9. [CrossRef]

66. Pousti, F.; Ahmadi, R.; Mirahmadi, F.; Hosseinmardi, N.; Rohampour, K. Adiponectin modulates synaptic plasticity in hippocampal dentate gyrus. Neurosci. Lett. 2018, 662, 227-232. [CrossRef]

67. Thundyil, J.; Pavlovski, D.; Sobey, C.G.; Arumugam, T.V. Adiponectin receptor signalling in the brain. Br. J. Pharmacol. 2011, 165, 313-327. [CrossRef] 
68. Li, X.-L.; Aou, S.; Oomura, Y.; Hori, N.; Fukunaga, K.; Hori, T. Impairment of long-term potentiation and spatial memory in leptin receptor-deficient rodents. Neuroscience 2002, 113, 607-615. [CrossRef]

69. Pérez-González, R.; Alvira-Botero, M.X.; Robayo, O.; Antequera, D.; Garzón, M.; Martín-Moreno, A.M.; Brera, B.; De Ceballos, M.L.; Carro, E. Leptin gene therapy attenuates neuronal damages evoked by amyloid- $\beta$ and rescues memory deficits in APP/PS1 mice. Gene Ther. 2014, 21, 298-308. [CrossRef]

70. Fewlass, D.C.; Noboa, K.; Pi-Sunyer, F.X.; Johnston, J.M.; Yan, S.D.; Tezapsidis, N. Obesity-related leptin regulates Alzheimer's Abeta. FASEB J. Off. Publ. Fed. Am. Soc. Exp. Biol. 2004, 18, 1870-1878.

71. Holden, K.F.; Lindquist, K.; Tylavsky, F.A.; Rosano, C.; Harris, T.B.; Yaffe, K. Serum leptin level and cognition in the elderly: Findings from the Health ABC Study. Neurobiol. Aging 2009, 30, 1483-1489. [CrossRef]

72. Ng, R.C.-L.; Chan, K.-H. Potential Neuroprotective Effects of Adiponectin in Alzheimer's Disease. Int. J. Mol. Sci. 2017, 18, 592. [CrossRef]

73. Kim, M.W.; Abid N bin Jo, M.H.; Jo, M.G.; Yoon, G.H.; Kim, M.O. Suppression of adiponectin receptor 1 promotes memory dysfunction and Alzheimer's disease-like pathologies. Sci. Rep. 2017, 7, 12435. [CrossRef]

74. Viswanathan, A.; Rocca, W.A.; Tzourio, C. Vascular risk factors and dementia: How to move forward? Neurology 2009, 72, 368-374. [CrossRef]

75. Borshchev, Y.Y.; Uspensky, Y.P.; Galagudza, M.M. Pathogenetic pathways of cognitive dysfunction and dementia in metabolic syndrome. Life Sci. 2019, 237, 116932. [CrossRef]

76. Pantoni, L. Cerebral small vessel disease: From pathogenesis and clinical characteristics to therapeutic challenges. Lancet Neurol. 2010, 9, 689-701. [CrossRef]

77. Moss, M.B.; Jonak, E. Cerebrovascular disease and dementia: A primate model of hypertension and cognition. Alzheimer's Dement. 2007, 3, S6-S15. [CrossRef]

78. Veglio, F.; Paglieri, C.; Rabbia, F.; Bisbocci, D.; Bergui, M.; Cerrato, P. Hypertension and cerebrovascular damage. Atherosclerosis 2009, 205, 331-341. [CrossRef]

79. Frisardi, V.; Solfrizzi, V.; Seripa, D.; Capurso, C.; Santamato, A.; Sancarlo, D.; Vendemiale, G.; Pilotto, A.; Panza, F. Metaboliccognitive syndrome: A cross-talk between metabolic syndrome and Alzheimer's disease. Ageing Res. Rev. 2010, 9, $399-417$. [CrossRef]

80. Reynolds, C.H.; Garwood, C.J.; Wray, S.; Price, C.; Kellie, S.; Perera, T.; Zvelebil, M.; Yang, A.; Sheppard, P.W.; Varndell, I.M.; et al. Phosphorylation Regulates Tau Interactions with Src Homology 3 Domains of Phosphatidylinositol 3-Kinase, Phospholipase C $\gamma 1$, Grb2, and Src Family Kinases. J. Biol. Chem. 2008, 283, 18177-18186. [CrossRef]

81. Marciniak, E.; Leboucher, A.; Caron, E.; Ahmed, T.; Tailleux, A.; Dumont, J.; Issad, T.; Gerhardt, E.; Pagesy, P.; Vileno, M.; et al. Tau deletion promotes brain insulin resistance. J. Exp. Med. 2017, 214, 2257-2269. [CrossRef] [PubMed]

82. Obici, S.; Feng, Z.; Karkanias, G.; Baskin, D.G.; Rossetti, L. Decreasing hypothalamic insulin receptors causes hyperphagia and insulin resistance in rats. Nat. Neurosci. 2002, 5, 566-572. [CrossRef] [PubMed]

83. Brüning, J.C.; Gautam, D.; Burks, D.J.; Gillette, J.; Schubert, M.; Orban, P.C.; Klein, R.; Krone, W.; Müller-Wieland, D.; Kahn, C.R. Role of brain insulin receptor in control of body weight and reproduction. Science 2000, 289, 2122-2125. [CrossRef]

84. Bharadwaj, P.; Wijesekara, N.; Liyanapathirana, M.; Newsholme, P.; Ittner, L.; Fraser, P.; Verdile, G. The Link between Type 2 Diabetes and Neurodegeneration: Roles for Amyloid- $\beta$, Amylin, and Tau Proteins. J. Alzheimer's Dis. 2017, 59, 421-432. [CrossRef]

85. Wijesekara, N.; Ahrens, R.; Sabale, M.; Wu, L.; Ha, K.; Verdile, G.; Fraser, P.E. Amyloid- $\beta$ and islet amyloid pathologies link Alzheimer's disease and type 2 diabetes in a transgenic model. FASEB J. Off. Publ. Fed. Am. Soc. Exp. Biol. 2017, 31, 5409-5418. [CrossRef]

86. Wijesekara, N.; Gonçalves, R.A.; Ahrens, R.; De Felice, F.G.; Fraser, P.E. Tau ablation in mice leads to pancreatic $\beta$ cell dysfunction and glucose intolerance. FASEB J. 2018, 32, 3166-3173. [CrossRef]

87. Xie, L.; Helmerhorst, E.; Taddei, K.; Plewright, B.; Van Bronswijk, W.; Martins, R. Alzheimer's beta-amyloid peptides compete for insulin binding to the insulin receptor. J. Neurosci. Off. J. Soc. Neurosci. 2002, 22, 221. [CrossRef]

88. Zhang, Y.; Zhou, B.; Zhang, F.; Wu, J.; Hu, Y.; Liu, Y.; Zhai, Q. Amyloid- $\beta$ induces hepatic insulin resistance by activating JAK2/STAT3/SOCS-1 signaling pathway. Diabetes 2012, 61, 1434-1443. [CrossRef]

89. De Felice, F.G.; Velasco, P.T.; Lambert, M.P.; Viola, K.; Fernandez, S.J.; Ferreira, S.T.; Klein, W.L. Abeta oligomers induce neuronal oxidative stress through an N-methyl-D-aspartate receptor-dependent mechanism that is blocked by the Alzheimer drug memantine. J. Biol. Chem. 2007, 282, 11590-11601. [CrossRef]

90. Kim, J.-A.; Wei, Y.; Sowers, J.R. Role of Mitochondrial Dysfunction in Insulin Resistance. Circ. Res. 2008, 102, 401-414. [CrossRef] [PubMed]

91. Zhao, W.; De Felice, F.G.; Fernandez, S.; Chen, H.; Lambert, M.P.; Quon, M.J.; Krafft, G.A.; Klein, W.L. Amyloid beta oligomers induce impairment of neuronal insulin receptors. FASEB J. 2007, 22, 246-260. [CrossRef]

92. Bomfim, T.R.; Forny-Germano, L.; Sathler, L.B.; Brito-Moreira, J.; Houzel, J.C.; Decker, H.; Silverman, M.A.; Kazi, H.; Melo, H.M.; McClean, P.L.; et al. An anti-diabetes agent protects the mouse brain from defective insulin signaling caused by Alzheimer's disease-associated A $\beta$ oligomers. J. Clin. Investig. 2012, 122, 1339-1353. [CrossRef]

93. Bonda, D.J.; Stone, J.G.; Torres, S.L.; Siedlak, S.L.; Perry, G.; Kryscio, R.; Jicha, G.; Casadesus, G.; Smith, M.A.; Zhu, X.; et al. Dysregulation of leptin signaling in Alzheimer disease: Evidence for neuronal leptin resistance. J. Neurochem. 2014, 128, 162-172. [CrossRef] 
94. Kanoski, S.E.; Hayes, M.R.; Greenwald, H.S.; Fortin, S.M.; Gianessi, C.A.; Gilbert, J.R.; Grill, H.J. Hippocampal Leptin Signaling Reduces Food Intake and Modulates Food-Related Memory Processing. Neuropsychopharmacology 2011, 36, 1859-1870. [CrossRef]

95. Meakin, P.J.; Jalicy, S.M.; Montagut, G.; Allsop, D.J.P.; Cavellini, D.L.; Irvine, S.W.; McGinley, C.; Liddell, M.K.; McNeilly, A.D.; Parmionova, K.; et al. Bace1-dependent amyloid processing regulates hypothalamic leptin sensitivity in obese mice. Sci. Rep. 2018, 8, 55. [CrossRef] [PubMed]

96. Brief, D.J.; Davis, J.D. Reduction of food intake and body weight by chronic intraventricular insulin infusion. Brain Res. Bull. 1984, 12, 571-575. [CrossRef]

97. Panza, F.; Solfrizzi, V.; Logroscino, G.; Maggi, S.; Santamato, A.; Seripa, D.; Pilotto, A. Current epidemiological approaches to the met-abolic-cognitive syndrome. J. Alzheimers Dis. 2012, 30, S31-S75. [CrossRef] [PubMed]

98. Irimata, K.E.; Dugger, B.N.; Wilson, J.R. Impact of the Presence of Select Cardiovascular Risk Factors on Cognitive Changes among Dementia Subtypes. Curr. Alzheimer Res. 2018, 15, 1032-1044. [CrossRef] [PubMed]

99. Case, C.C.; Jones, P.H.; Nelson, K.; Smith, E.O.; Ballantyne, C.M. Impact of weight loss on the metabolic syndrome. Diabetes Obes. Metab. 2002, 4, 407-414. [CrossRef] [PubMed]

100. Yaffe, K.; Kanaya, A.; Lindquist, K.; Simonsick, E.M.; Harris, T.; Shorr, R.I.; Tylavsky, F.A.; Newman, A.B. The Metabolic Syndrome, Inflammation, and Risk of Cognitive Decline. JAMA 2004, 292, 2237-2242. [CrossRef] [PubMed]

101. Panza, F.; D’Introno, A.; Colacicco, A.M.; Capurso, C.; Del Parigi, A.; Capurso, S.A.; Caselli, R.J.; Pilotto, A.; Scafato, E.; Capurso, A.; et al. Cognitive frailty: Predementia syndrome and vascular risk factors. Neurobiol. Aging 2006, 27, 933-940. [CrossRef]

102. Dregan, A.; Stewart, R.; Gulliford, M.C. Cardiovascular risk factors and cognitive decline in adults aged 50 and over: A popula-tion-based cohort study. Age Ageing 2013, 42, 338-345. [CrossRef]

103. Harrison, S.L.; Ding, J.; Tang, E.Y.H.; Siervo, M.; Robinson, L.; Jagger, C.; Stephan, B.C.M. Cardiovascular Disease Risk Models and Longitudinal Changes in Cognition: A Systematic Review. PLoS ONE 2014, 9, e114431. [CrossRef] [PubMed]

104. Harrison, S.L.; De Craen, A.J.M.; Kerse, N.; Teh, R.; Granic, A.; Davies, K.; Wesnes, K.A.; Elzen, W.D.; Gussekloo, J.; Kirkwood, T.B.L.; et al. Predicting Risk of Cognitive Decline in Very Old Adults Using Three Models: The Framingham Stroke Risk Profile; the Cardiovascular Risk Factors, Aging, and Dementia Model; and Oxi-Inflammatory Biomarkers. J. Am. Geriatr. Soc. 2017, 65, 381-389. [CrossRef] [PubMed]

105. Purnell, C.; Gao, S.; Callahan, C.M.; Hendrie, H.C. Cardiovascular risk factors and incident Alzheimer disease: A systematic review of the literature. Alzheimer Dis. Assoc. Disord. 2009, 23, 1-10. [CrossRef]

106. Prasad, K.; Wiryasaputra, L.; Ng, A.; Kandiah, N. White Matter Disease Independently Predicts Progression from Mild Cognitive Impairment to Alzheimer's Disease in a Clinic Cohort. Dement. Geriatr. Cogn. Disord. 2011, 31, 431-434. [CrossRef]

107. Iadecola, C.; Yaffe, K.; Biller, J.; Bratzke, L.C.; Faraci, F.M.; Gorelick, P.B.; Gulati, M.; Kamel, H.; Knopman, D.S.; Launer, L.J.; et al. Impact of Hypertension on Cognitive Function: A Scientific Statement from the American Heart Association. Hypertension 2016, 68, e67-e94. [CrossRef] [PubMed]

108. Avila Vinueza, J.P.; Avila Vinueza, T.L.; Pesantez Calle, M.F.; Guaraca Pino, A.C.; Durazno Montesdeoca, G.C.; Cobos Alvarracin, M.Y. Frecuencia, factores de riesgo y hallazgos neuroimagenológicos de deterioro cognitivo leve en pacientes con hipertensión arterial. Arch. Venez. Farmacol. Ter. 2019, 38, 12.

109. McDonald, C.; Pearce, M.S.; Kerr, S.R.J.; Newton, J.L. Blood pressure variability and cognitive decline in older people: A 5-year longitudinal study. J. Hypertens. 2017, 35, 140-147. [CrossRef]

110. Tzourio, C.; Dufouil, C.; Ducimetiere, P.; Alperovitch, A. Cognitive decline in individuals with high blood pressure: A longitudinal study in the elderly. Neurology 1999, 53, 1948. [CrossRef]

111. Haring, B.; Wu, C.; Coker, L.H.; Seth, A.; Snetselaar, L.; Manson, J.E.; Rossouw, J.E.; Wassertheil-Smoller, S. Hypertension, Dietary Sodium, and Cognitive Decline: Results from the Women's Health Initiative Memory Study. Am. J. Hypertens. 2015, 29, $202-216$. [CrossRef]

112. Tarraf, W.; Rodríguez, C.J.; Daviglus, M.L.; Lamar, M.; Schneiderman, N.; Gallo, L.; Talavera, G.A.; Kaplan, R.C.; Fornage, M.; Conceicao, A.; et al. Blood Pressure and Hispanic/Latino Cognitive Function: Hispanic Community Health Study/Study of Latinos Results. J. Alzheimer's Dis. 2017, 59, 31-42. [CrossRef]

113. Kilander, L.; Nyman, H.; Boberg, M.; Hansson, L.; Lithell, H. Hypertension is related to cognitive impairment: A 20-year follow-up of 999 men. Hypertension 1998, 31, 780-786. [CrossRef] [PubMed]

114. Launer, L.J. The association between midlife blood pressure levels and late-life cognitive function. The Honolulu-Asia Aging Study. JAMA 1995, 274, 1846-1851. [CrossRef] [PubMed]

115. Walker, K.A.; Sharrett, A.R.; Wu, A.; Schneider, A.L.C.; Albert, M.; Lutsey, P.L.; Bandeen-Roche, K.; Coresh, J.; Gross, A.L.; Windham, B.G.; et al. Association of Midlife to Late-Life Blood Pressure Patterns with Incident Dementia. JAMA 2019, 322, 535-545. [CrossRef] [PubMed]

116. Reitz, C.; Tang, M.-X.; Manly, J.; Mayeux, R.; Luchsinger, J.A. Hypertension and the Risk of Mild Cognitive Impairment. Arch Neurol. 2007, 64, 1734-1740. [CrossRef] [PubMed]

117. Elias, M.F.; Elias, P.K.; Sullivan, L.M.; Wolf, P.A.; D'Agostino, R.B. Lower cognitive function in the presence of obesity and hyper-tension: The Framingham heart study. Int. J. Obes. Relat. Metab. Disord. J. Int. Assoc. Study Obes. 2003, 27, 260-268. [CrossRef] [PubMed] 
118. Chacón, O.; Riaño-Garzón, M.E.; Bermúdez, V.; Quintero Sanguino, M.; Hernández Lalinde, J.D.; Mendoza Bernal, M.I. ¿Es la obesidad un factor de riesgo para el trastorno de déficit de atención con hiperactividad (TDAH)? Rev. Latinoam Hipertens. 2018, 13, 89-97.

119. Cournot, M.; Marquie, J.C.; Ansiau, D.; Martinaud, C.; Fonds, H.; Ferrieres, J.; Ruidavets, J.B. Relation between body mass index and cognitive function in healthy middle-aged men and women. Neurology 2006, 67, 1208-1214. [CrossRef]

120. Kloppenborg, R.P.; Berg, E.V.D.; Kappelle, L.J.; Biessels, G.J. Diabetes and other vascular risk factors for dementia: Which factor matters most? A systematic review. Eur. J. Pharmacol. 2008, 585, 97-108. [CrossRef]

121. Sabia, S.; Kivimaki, M.; Shipley, M.J.; Marmot, M.; Singh-Manoux, A. Body mass index over the adult life course and cognition in late midlife: The Whitehall II Cohort Study. Am. J. Clin. Nutr. 2008, 89, 601-607. [CrossRef]

122. Beydoun, M.A.; Wang, Y. Obesity and central obesity as risk factors for incident dementia and its subtypes: A systematic review and meta-analysis. Obes. Rev. 2008, 9, 204-218. [CrossRef] [PubMed]

123. Blom, K.; Emmelot-Vonk, M.H.; Koek, H.L. The influence of vascular risk factors on cognitive decline in patients with dementia: A systematic review. Maturitas 2013, 76, 113-117. [CrossRef]

124. de Frias, C.M.; Bunce, D.; Wahlin, A.; Adolfsson, R.; Sleegers, K.; Cruts, M.; van Broeckhoven, C.; Nilsson, L. Cholesterol and triglycerides moderate the effect of apolipoprotein E on memory functioning in older adults. J. Gerontol. B Psychol. Sci. Soc. Sci. 2007, 62, 112-118. [CrossRef] [PubMed]

125. Sims, R.; Madhere, S.; Callender, C.; Campbell, A. Patterns of Relationships between Cardiovascular Disease Risk Factors and Neurocognitive Function in African Americans. Ethn. Dis. 2008, 18, 471-476. [PubMed]

126. Singh-Manoux, A.; Gimeno, D.; Kivimaki, M.; Brunner, E.; Marmot, M.G. Low HDL cholesterol is a risk factor for deficit and decline in memory in midlife: The Whitehall II study. Arterioscler Thromb. Vasc. Biol. 2008, 28, 1556-1562. [CrossRef]

127. Zuliani, G.; Cavalieri, M.; Galvani, M.; Volpato, S.; Cherubini, A.; Bandinelli, S.; Corsi, A.M.; Lauretani, F.; Guralnik, J.M.; Fellin, R.; et al. Relationship Between Low Levels of High-Density Lipoprotein Cholesterol and Dementia in the Elderly. The InChianti Study. J. Gerontol. Ser. A Biol. Sci. Med. Sci. 2010, 65, 559-564. [CrossRef] [PubMed]

128. van Vliet, P.; van de Water, W.; de Craen, A.J.M.; Westendorp, R.G.J. The influence of age on the association between cholesterol and cognitive function. Exp. Gerontol. 2009, 44, 112-122. [CrossRef]

129. Kinno, R.; Mori, Y.; Kubota, S.; Nomoto, S.; Futamura, A.; Shiromaru, A.; Kuroda, T.; Yano, S.; Ishigaki, S.; Murakami, H.; et al. High serum high-density lipoprotein-cholesterol is associated with memory function and gyrification of insular and frontal opercular cortex in an elderly memory-clinic pop-ulation. NeuroImage Clin. 2019, 22, 101746. [CrossRef]

130. Bonarek, M.; Barberger-Gateau, P.; Letenneur, L.; Deschamps, V.; Iron, A.; Dubroca, B.; Dartigues, J.F. Relationships between cholesterol, apolipoprotein E polymorphism and dementia: A cross-sectional analysis from the PAQUID study. Neuroepidemiology 2000, 19, 141-148. [CrossRef]

131. Sanz, C.; Andrieu, S.; Sinclair, A.; Hanaire, H.; Vellas, B. For the REAL.FR Study Group Diabetes is associated with a slower rate of cognitive decline in Alzheimer disease. Neurology 2009, 73, 1359-1366. [CrossRef]

132. Solimany, F.; Mohammadi, E.; Omidfar, F. Comparison of cognitive abilities, depression and anxiety of type II diabetic patients with healthy individuals in Isfahan province in 2015. Rev. Latinoam. Hipertens. 2018, 13, 8.

133. Marseglia, A.; Fratiglioni, L.; Kalpouzos, G.; Wang, R.; Bäckman, L.; Xu, W. Prediabetes and diabetes accelerate cognitive decline and predict microvascular lesions: A population-based cohort study. Alzheimer's Dement. 2019, 15, 25-33. [CrossRef]

134. Rouch, I.; Roche, F.; Dauphinot, V.; Laurent, B.; Antérion, C.T.; Celle, S.; Krolak-Salmon, P.; Barthélémy, J.-C. Diabetes, impaired fasting glucose, and cognitive decline in a population of elderly community residents. Aging Clin. Exp. Res. 2012, 24, 377-383. [CrossRef] [PubMed]

135. Yaffe, K.; Blackwell, T.; Kanaya, A.M.; Davidowitz, N.; Barrett-Connor, E.; Krueger, K. Diabetes, impaired fasting glucose, and development of cognitive impairment in older women. Neurology 2004, 63, 658-663. [CrossRef] [PubMed]

136. Vanhanen, M.; Koivisto, K.; Kuusisto, J.; Mykkänen, L.; Helkala, E.-L.; Hänninen, T.; Riekkinen, P.; Soininen, H.; Laakso, M. Cognitive function in an elderly population with persistent impaired glucose tolerance. Diabetes Care 1998, 21, 398-402. [CrossRef] [PubMed]

137. Kanaya, A.M.; Barrett-Connor, E.; Gildengorin, G.; Yaffe, K. Change in cognitive function by glucose tolerance status in older adults: A 4-year prospective study of the Rancho Bernardo study cohort. Arch. Intern. Med. 2004, 164, 1327-1333. [CrossRef]

138. Miles, W.R.; Root, H.F. Psychologic Tests Applied to Diabetic Patients. Arch. Intern. Med. 1922, 30, 767-777. [CrossRef]

139. Grodstein, F.; Chen, J.; Wilson, R.S.; Manson, J.E. Nurses' Health Study. Type 2 diabetes and cognitive function in communi-tydwelling elderly women. Diabetes Care. 2001, 24, 1060-1065. [CrossRef] [PubMed]

140. Cukierman, T.; Gerstein, H.C.; Williamson, J.D. Cognitive decline and dementia in diabetes—systematic overview of prospective observational studies. Diabetologia 2005, 48, 2460-2469. [CrossRef]

141. Saczynski, J.S.; Jónsdóttir, M.K.; Garcia, M.E.; Jonsson, P.V.; Peila, R.; Eiriksdottir, G.; Olafsdottir, E.; Harris, T.B.; Gudnason, V.; Launer, L.J. Cognitive Impairment: An Increasingly Important Complication of Type 2 Diabetes: The Age, Gene/Environment Susceptibility-Reykjavik Study. Am. J. Epidemiol. 2008, 168, 1132-1139. [CrossRef]

142. Cukierman-Yaffe, T.; Gerstein, H.C.; Williamson, J.D.; Lazar, R.M.; Lovato, L.; Miller, M.E.; Coker, L.H.; Murray, A.; Sullivan, M.D.; Marcovina, S.M.; et al. Relationship between baseline gly-cemic control and cognitive function in individuals with type 2 diabetes and other cardiovascular risk factors: The action to control cardiovascular risk in diabetes-memory in diabetes (ACCORD-MIND) trial. Diabetes Care 2009, 32, 221-226. [CrossRef] 
143. Elias, M.F.; Elias, P.K.; Sullivan, L.M.; Wolf, P.A.; D'Agostino, R.B. Obesity, diabetes and cognitive deficit: The Framingham Heart Study. Neurobiol. Aging 2005, 26, 11-16. [CrossRef] [PubMed]

144. Roberts, R.O.; Geda, Y.E.; Knopman, D.S.; Cha, R.H.; Boeve, B.F.; Ivnik, R.J.; Pankratz, V.S.; Tangalos, E.G.; Petersen, R.C. Metabolic syndrome, inflammation, and nonamnestic mild cognitive impairment in older persons: A population-based study. Alzheimer Dis. Assoc. Disord. 2010, 24, 11-18. [CrossRef] [PubMed]

145. Yaffe, K.; Weston, A.L.; Blackwell, T.; Krueger, K.A. The Metabolic Syndrome and Development of Cognitive Impairment Among Older Women. Arch. Neurol. 2009, 66, 324-328. [CrossRef]

146. Pal, K.; Mukadam, N.; Petersen, I.; Cooper, C. Mild cognitive impairment and progression to dementia in people with diabetes, prediabetes and metabolic syndrome: A systematic review and meta-analysis. Soc. Psychiatry Psychiatr. Epidemiol. 2018, 53, 1149-1160. [CrossRef] [PubMed]

147. Atti, A.R.; Valente, S.; Iodice, A.; Caramella, I.; Ferrari, B.; Albert, U.; Mandelli, L.; De Ronchi, D. Metabolic Syndrome, Mild Cognitive Impairment, and Dementia: A Meta-Analysis of Longitudinal Studies. Am. J. Geriatr. Psychiatry 2019, $27,625-637$. [CrossRef] [PubMed]

148. Yau, P.L.; Javier, D.C.; Ryan, C.; Tsui, W.H.; Ardekani, B.A.; Ten, S.; Convit, A. Preliminary evidence for brain complications in obese adolescents with type 2 diabetes mellitus. Diabetologia 2010, 53, 2298-2306. [CrossRef]

149. Verdejo-Garcia, A.; Pérez-Expósito, M.; Schmidt-Río-Valle, J.; Fernández-Serrano, M.J.; Cruz, F.; Pérez-García, M.; López-Belmonte, G.; Martín-Matillas, M.; Martín-Lagos, J.A.; Marcos, A.; et al. Selective Alterations Within Executive Functions in Adolescents With Excess Weight. Obesity 2010, 18, 1572-1578. [CrossRef]

150. Lande, M.B.; Kaczorowski, J.M.; Auinger, P.; Schwartz, G.J.; Weitzman, M. Elevated blood pressure and decreased cognitive function among school-age children and adolescents in the United States. J. Pediatr. 2003, 143, 720-724. [CrossRef]

151. Li, Y.; Dai, Q.; Jackson, J.C.; Zhang, J. Overweight Is Associated with Decreased Cognitive Functioning Among School-age Children and Adolescents. Obesity 2008, 16, 1809-1815. [CrossRef]

152. Lozada, M.; Machado, S.; Manrique, M.; Martínez, D.; Suárez, O.; Guevara, H. Factores de riesgo asociados al síndrome metabólico en adolescentes. Gac. Médica Caracas 2008, 116, 323-329.

153. Bourdel-Marchasson, I.; Lapre, E.; Laksir, H.; Puget, E. Insulin resistance, diabetes and cognitive function: Consequences for pre-ventative strategies. Diabetes Metab. 2010, 36, 173-181. [CrossRef]

154. Pinillos Patiño, Y.; Herazo Beltrán, Y.; Vidarte Claros, J.A.; Quiroz, E.; Suarez Palacio, D. Niveles de Actividad Física y sus Deter-minantes en Mujeres Adultas de Barranquilla. Cienc. Innov. Salud 2014, 2, 10-17.

155. De La Cruz Vargas, J.A.; Dyzinger, W.; Herzog, S.; dos Santos, F.; Villegas, H.; Ezinga, M. Medicina del Estilo de Vida: Trabajando juntos para revertir la epidemia de las enfermedades crónicas en Latinoamérica. Cienc. Innov. Salud 2017, 4, 1-7. [CrossRef]

156. Frederiksen, K.S.; Verdelho, A.; Madureira, S.; Bäzner, H.; O’Brien, J.T.; Fazekas, F.; Scheltens, P.; Schmidt, R.; Wallin, A.; Wahlund, L.; et al. Physical activity in the elderly is associated with improved executive function and processing speed: The LADIS Study: Physical activity and cognitive function. Int. J. Geriatr. Psychiatry. 2015, 30, 744-750. [CrossRef] [PubMed]

157. Karssemeijer, E.G.A.; Aaronson, J.A.; Bossers, W.J.; Smits, T.; Olde Rikkert, M.G.M.; Kessels, R.P.C. Positive effects of combined cognitive and physical exercise training on cognitive function in older adults with mild cognitive impairment or dementia: A me-ta-analysis. Ageing Res. Rev. 2017, 40, 75-83. [CrossRef] [PubMed]

158. Groot, C.; Hooghiemstra, A.; Raijmakers, P.; Van Berckel, B.; Scheltens, P.; Scherder, E.; van der Flier, W.; Ossenkoppele, R. The effect of physical activity on cognitive function in patients with dementia: A meta-analysis of randomized control trials. Ageing Res. Rev. 2016, 25, 13-23. [CrossRef]

159. Díaz Cárdenas, S. Fomento de la Salud Física en Pacientes de la Facultad de Odontología de la Universidad de Cartagena: Sistematización de Experiencias. Cienc. Innov. Salud 2013, 1, 52-56. [CrossRef]

160. Lautenschlager, N.T.; Cox, K.L.; Ellis, K.A. Physical activity for cognitive health: What advice can we give to older adults with subjective cognitive decline and mild cognitive impairment? Dialogues Clin. Neurosci. 2019, 21, 61-68. [PubMed]

161. McGrattan, A.M.; McEvoy, C.; McGuinness, B.; McKinley, M.C.; Woodside, J.V. Effect of dietary interventions in mild cognitive impairment: A systematic review. Br. J. Nutr. 2018, 120, 1388-1405. [CrossRef] [PubMed]

162. Singh, B.; Parsaik, A.K.; Mielke, M.; Erwin, P.J.; Knopman, D.S.; Petersen, R.C.; Roberts, R.O. Association of Mediterranean Diet with Mild Cognitive Impairment and Alzheimer's Disease: A Systematic Review and Meta-Analysis. J. Alzheimer's Dis. 2014, 39, 271-282. [CrossRef] [PubMed]

163. Hosking, D.E.; Eramudugolla, R.; Cherbuin, N.; Anstey, K.J. MIND not Mediterranean diet related to 12-year incidence of cognitive impairment in an Australian longitudinal cohort study. Alzheimer's Dement. 2019, 15, 581-589. [CrossRef]

164. Krikorian, R.; Shidler, M.D.; Dangelo, K.; Couch, S.C.; Benoit, S.C.; Clegg, D.J. Dietary ketosis enhances memory in mild cognitive impairment. Neurobiol. Aging 2012, 33, 425.e19-425.e27. [CrossRef] [PubMed]

165. Zhang, Y.; Chen, J.; Qiu, J.; Li, Y.; Wang, J.; Jiao, J. Intakes of fish and polyunsaturated fatty acids and mild-to-severe cognitive impairment risks: A dose-response meta-analysis of 21 cohort studies1-3. Am. J. Clin. Nutr. 2015, 103, 330-340. [CrossRef] [PubMed]

166. Rouch, L.; Cestac, P.; Hanon, O.; Cool, C.; Helmer, C.; Bouhanick, B.; Chamontin, B.; Dartigues, J.-F.; Vellas, B.; Andrieu, S. Antihypertensive Drugs, Prevention of Cognitive Decline and Dementia: A Systematic Review of Observational Studies, Randomized Controlled Trials and Meta-Analyses, with Discussion of Potential Mechanisms. CNS Drugs 2015, 29, 113-130. [CrossRef] [PubMed] 
167. Levi Marpillat, N.; Macquin-Mavier, I.; Tropeano, A.I.; Bachoud-Levi, A.-C.; Maison, P. Antihypertensive classes, cognitive decline and incidence of dementia: A network meta-analysis. J. Hypertens. 2013, 31, 1073-1082. [CrossRef]

168. Guo, Z.; Fratiglioni, L.; Zhu, L.; Fastbom, J.; Winblad, B.; Viitanen, M. Occurrence and progression of dementia in a community population aged 75 years and older: Relationship of antihypertensive medication use. Arch. Neurol. 1999, 56, 991-996. [CrossRef]

169. Zhang, Q.Q.; Li, W.S.; Liu, Z.; Zhang, H.L.; Ba, Y.G.; Zhang, R.X. Metformin therapy and cognitive dysfunction in patients with type 2 diabetes: A meta-analysis and systematic review. Medicine 2020, 99, 19378. [CrossRef]

170. Ng, T.P.; Feng, L.; Yap, K.B.; Lee, T.S.; Tan, C.H.; Winblad, B. Long-Term Metformin Usage and Cognitive Function among Older Adults with Diabetes. J. Alzheimer's Dis. 2014, 41, 61-68. [CrossRef]

171. Borzì, A.M.; Condorelli, G.; Biondi, A.; Basile, F.; Vicari, E.S.D.; Buscemi, C.; Luca, S.; Vacante, M. Effects of vildagliptin, a DPP-4 inhibitor, in elderly diabetic patients with mild cognitive impairment. Arch. Gerontol. Geriatr. 2019, 84, 103896. [CrossRef]

172. Areosa Sastre, A.; Vernooij, R.W.; González-Colaço Harmand, M.; Martínez, G. Effect of the treatment of Type 2 diabetes mellitus on the development of cognitive impairment and dementia. Cochrane Database Syst. Rev. 2017, 6, 003804. [CrossRef]

173. Koo, B.K.; Kim, L.; Lee, J.; Moon, M.K. Taking metformin and cognitive function change in older patients with diabetes. Geriatr. Gerontol. Int. 2019, 19, 755-761. [CrossRef] [PubMed]

174. Wennberg, A.M.V.; Hagen, C.E.; Edwards, K.; Roberts, R.O.; Machulda, M.M.; Knopman, D.S.; Petersen, R.C.; Mielke, M.M. Association of antidiabetic medi-cation use, cognitive decline, and risk of cognitive impairment in older people with type 2 diabetes: Results from the pop-ulation-based Mayo Clinic Study of Aging. Int. J. Geriatr. Psychiatry. 2018, 33, 1114-1120. [CrossRef] [PubMed]

175. Fink, H.A.; Jutkowitz, E.; McCarten, J.R.; Hemmy, L.S.; Butler, M.; Davila, H.; Ratner, E.; Calvert, C.; Barclay, T.R.; Brasure, M. Pharmacologic interventions to prevent cognitive decline, mild cognitive impairment, and clinical Alzheimer-type dementia: A systematic review. Ann. Intern. Med. 2018, 168, 39-51. [CrossRef]

176. Ligthart, S.A.; Moll van Charante, E.P.; Van Gool, W.A.; Richard, E. Treatment of cardiovascular risk factors to prevent cognitive decline and dementia: A systematic review. Vasc. Health Risk Manag. 2010, 6, 775-785. [CrossRef] [PubMed]

177. Bosch, J.; O’Donnell, M.; Swaminathan, B.; Lonn, E.M.; Sharma, M.; Dagenais, G.; Diaz, R.; Khunit, K.; Lewis, B.S.; Avezum, A.; et al. Effects of blood pressure and lipid lowering on cognition: Results from the HOPE-3 study. Neurology 2019, 92, 1435-1446. [CrossRef]

178. Bettermann, K.; Arnold, A.M.; Williamson, J.; Rapp, S.; Sink, K.; Toole, J.F.; Carlson, M.C.; Yasar, S.; DeKosky, S.; Burke, G.L. Statins, Risk of Dementia, and Cognitive Function: Secondary Analysis of the Ginkgo Evaluation of Memory Study. J. Stroke Cerebrovasc. Dis. 2012, 21, 436-444. [CrossRef]

179. Zandi, P.P.; Sparks, D.L.; Khachaturian, A.S.; Tschanz, J.; Norton, M.; Steinberg, M.; Welsh-Bohmer, K.A.; Breitner, J.C.S. Do Statins Reduce Risk of Incident Dementia and Alzheimer Disease? The Cache County Study. Arch. Gen. Psychiatry 2005, 62, 217-224. [CrossRef]

180. Rea, T.D.; Breitner, J.C.; Psaty, B.M.; Fitzpatrick, A.L.; Lopez, O.L.; Newman, A.B.; Hazzard, W.R.; Zandi, P.P.; Burke, G.L.; Lyketsos, C.G.; et al. Statin use and the risk of incident dementia: The cardiovascular health study. Arch. Neurol. 2005, 62, 1047-1051. [CrossRef]

181. Bae, S.; Shimada, H.; Lee, S.; Makizako, H.; Lee, S.; Harada, K.; Doi, T.; Tsutsumimoto, K.; Hotta, R.; Nakakubo, S.; et al. The Relationships Between Components of Metabolic Syndrome and Mild Cognitive Impairment Subtypes: A Cross-Sectional Study of Japanese Older Adults. J. Alzheimer's Dis. 2017, 60, 913-921. [CrossRef]

182. Steen, E.; Terry, B.M.; Rivera, E.J.; Cannon, J.L.; Neely, T.R.; Tavares, R.; Xu, X.J.; Wands, J.R.; De La Monte, S.M. Impaired insulin and insulin-like growth factor expression and signaling mechanisms in Alzheimer's disease-Is this type 3 diabetes? J. Alzheimer's Dis. 2005, 7, 63-80. [CrossRef] [PubMed]

183. Frölich, L.; Blum-Degen, D.; Bernstein, H.-G.; Engelsberger, S.; Humrich, J.; Laufer, S.; Muschner, D.; Thalheimer, A.; Türk, A.; Hoyer, S.; et al. Brain insulin and insulin receptors in aging and sporadic Alzheimer's disease. J. Neural Transm. 1998, 105, 423-438. [CrossRef] [PubMed]

184. Craft, S.; Peskind, E.; Schwartz, M.W.; Schellenberg, G.D.; Raskind, M.; Porte, D. Cerebrospinal fluid and plasma insulin levels in Alzheimer's disease: Relationship to severity of dementia and apolipoprotein E genotype. Neurology 1998, 50, 164-168. [CrossRef]

185. Mody, N.; Agouni, A.; Mcilroy, G.D.; Platt, B.; Delibegovic, M. Susceptibility to diet-induced obesity and glucose intolerance in the APP SWE/PSEN1 A246E mouse model of Alzheimer's disease is associated with increased brain levels of protein tyrosine phosphatase 1B (PTP1B) and retinol-binding protein 4 (RBP4), and basal phosphorylation of S6 ribosomal protein. Diabetologia 2011, 54, 2143-2151. [CrossRef] [PubMed]

186. Janson, J.; Laedtke, T.; Parisi, J.E.; O’Brien, P.; Petersen, R.C.; Butler, P.C. Increased Risk of Type 2 Diabetes in Alzheimer Disease. Diabetes 2004, 53, 474-481. [CrossRef] [PubMed]

187. Altschul, D.M.; Starr, J.M.; Deary, I.J. Cognitive function in early and later life is associated with blood glucose in older individuals: Analysis of the Lothian Birth Cohort of 1936. Diabetologia 2018, 61, 1946-1955. [CrossRef]

188. Peng, X.; Xu, Z.; Mo, X.; Guo, Q.; Yin, J.; Xu, M.; Peng, Z.; Sun, T.; Zhou, L.; Peng, X.; et al. Association of plasma $\beta$-amyloid 40 and 42 concentration with type 2 diabetes among Chinese adults. Diabetologia 2020, 63, 954-963. [CrossRef]

189. Lipton, S.A. Paradigm shift in NMDA receptor antagonist drug development: Molecular mechanism of uncompetitive inhi-bition by memantine in the treatment of Alzheimer's disease and other neurologic disorders. J. Alzheimers Dis. 2004, 6, 61-74. [CrossRef] 
190. Ettcheto, M.; Sanchez-Lopez, E.; Gómez-Mínguez, Y.; Cabrera, H.; Busquets, O.; Beas-Zárate, C.; García, M.L.; Carro, E.; Casadesus, G.; Auladell, C.; et al. Peripheral and Central Effects of Memantine in a Mixed Preclinical Mice Model of Obesity and Familial Alzheimer's Disease. Mol. Neurobiol. 2018, 55, 7327-7339. [CrossRef]

191. Ahmed, A.S.; Elgharabawy, R.; Al-Najjar, A.H. Ameliorating effect of anti-Alzheimer's drugs on the bidirectional association between type 2 diabetes mellitus and Alzheimer's disease. Exp. Biol. Med. 2017, 242, 1335-1344. [CrossRef] [PubMed]

192. Meakin, P.J.; Harper, A.J.; Hamilton, D.L.; Gallagher, J.; McNeilly, A.D.; Burgess, L.A.; Vaanholt, L.M.; Bannon, K.A.; Latcham, J.; Hussain, I.; et al. Reduction in BACE1 decreases body weight, protects against diet-induced obesity and enhances insulin sensitivity in mice. Biochem. J. 2011, 441, 285-296. [CrossRef] [PubMed]

193. Wessels, A.M.; Tariot, P.N.; Zimmer, J.A.; Selzler, K.J.; Bragg, S.M.; Andersen, S.W.; Landry, J.; Krull, J.H.; Downing, A.M.; Willis, B.A.; et al. Efficacy and safety of Lanabecestat for treatment of early and mild Alzheimer disease: The AMARANTH and DAYBREAK-ALZ randomized clinical trials. JAMA Neurol. 2020, 77, 199-209. [CrossRef] [PubMed]

194. Zhang, Y.; Zhou, B.; Deng, B.; Zhang, F.; Wu, J.; Wang, Y.; Le, Y.; Zhai, Q. Amyloid- $\beta$ Induces Hepatic Insulin Resistance In Vivo via JAK2. Diabetes 2012, 62, 1159-1166. [CrossRef] [PubMed]

195. Gunstad, J.; Spitznagel, M.B.; Paul, R.H.; Cohen, R.A.; Kohn, M.; Luyster, F.S.; Clark, R.; Williams, L.M.; Gordon, E. Body mass index and neuropsychological function in healthy children and adolescents. Appetite 2008, 50, 246-251. [CrossRef]

196. Muller, M.; Tang, M.-X.; Schupf, N.; Manly, J.J.; Mayeux, R.; Luchsinger, J.A. Metabolic Syndrome and Dementia Risk in a Multiethnic Elderly Cohort. Dement. Geriatr. Cogn. Disord. 2007, 24, 185-192. [CrossRef]

197. Forti, P.; Pisacane, N.; Rietti, E.; Lucicesare, A.; Olivelli, V.; Mariani, E.; Mecocci, P.; Ravaglia, G. Metabolic Syndrome and Risk of Dementia in Older Adults. J. Am. Geriatr. Soc. 2010, 58, 487-492. [CrossRef]

198. Feinkohl, I.; Janke, J.; Hadzidiakos, D.; Slooter, A.; Winterer, G.; Spies, C.; Pischon, T. Associations of the metabolic syndrome and its components with cognitive impairment in older adults. BMC Geriatr. 2019, 19, 1-11. [CrossRef] 